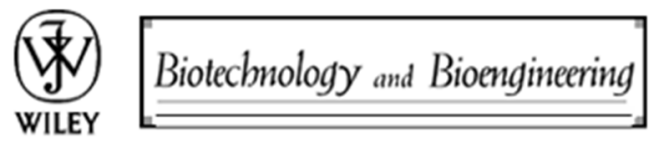

\title{
How does mild hypothermia affect monoclonal antibody glycosylation?
}

\begin{tabular}{|r|l|}
\hline Journal: & Biotechnology and Bioengineering \\
\hline Manuscript ID: & Draft \\
\hline Datey - Manuscript type: & Article \\
\hline Complete List of Authors: & $\begin{array}{l}\text { Sou, Si; Imperial College London, Chemical Engineering } \\
\text { Sellick, Christopher; MedImmune, MedImmune } \\
\text { Lee, Ken; MedImmune, MedImmune } \\
\text { Mason, Alison; MedImmune, MedImmune } \\
\text { Kyriakopoulos, Sarantos; Imperial College London, Chemical Engineering } \\
\text { Polizzi, Karen; Imperial College London, Life Sciences } \\
\text { Kontoravdi, Cleo; Imperial College London, Chemical Engineering }\end{array}$ \\
\hline Key Words: & $\begin{array}{l}\text { Mild hypothermia, cell metabolism, glycosylation, mAb productivity, } \\
\text { glycosyltransferase, flux balance analysis }\end{array}$ \\
\hline & \multicolumn{2}{|l}{} \\
\hline
\end{tabular}


How does mild hypothermia affect monoclonal antibody glycosylation?

Running title: Examining links between cell metabolism and rProtein glycosylation

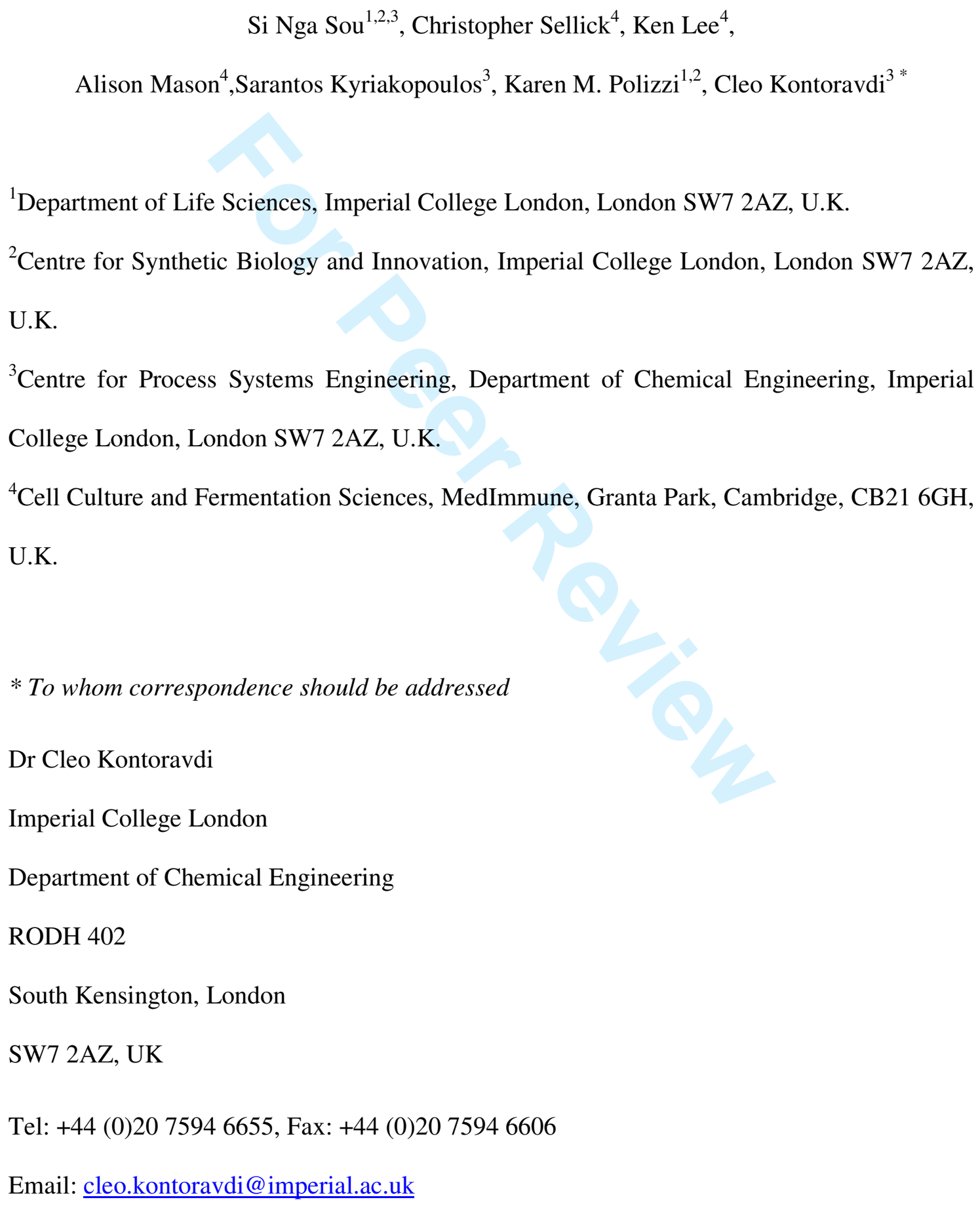




\begin{abstract}
The application of mild hypothermic conditions to cell culture is a routine industrial practice used to improve recombinant protein production. However, a thorough understanding of the regulation of dynamic cellular processes at lower temperatures is necessary to enhance bioprocess design and optimisation. In this study, we investigated the impact of mild hypothermia, where Chinese hamster ovary $(\mathrm{CHO})$ cells expressing a mAb were cultured at $36.5^{\circ} \mathrm{C}$ and with a temperature shift to $32^{\circ} \mathrm{C}$ during late exponential/early stationary phase, on protein glycosylation. Experimental results showed higher cell viability with decreased metabolic rates. The specific antibody productivity increased by $46.2 \%$ at $32^{\circ} \mathrm{C}$ and was accompanied by a reduction in intracellular nucleotide sugar concentrations and a decreased proportion of the more processed glycan structures on the IgG molecules. To better understand $\mathrm{CHO}$ cell metabolism at $32^{\circ} \mathrm{C}$, flux balance analysis (FBA) was carried out and constrained with exometabolite data from stationary phase of cultures with or without a temperature shift. Estimated fluxomes suggested reduced fluxes of carbon species towards nucleotide and nucleotide sugar donor synthesis, and more energy was used for product formation. Expression of $\mathrm{N}$-glycosyltransferases that are responsible for $\mathrm{N}$-glycan branching and elongation were significantly lower at $32^{\circ} \mathrm{C}$. As a result of mild hypothermia, mAb glycosylation was shown to be affected by both nucleotide sugar donor availability and glycosyltransferase expression. The combined experimental/FBA approach generated a more fundamental view of how product glycosylation can be impacted by changes in culture temperature. Better feeding strategies can therefore be developed based on the understanding of the metabolic flux distribution.
\end{abstract}




\section{Keywords}

Mild hypothermia, cell metabolism, glycosylation, mAb productivity, glycosyltransferase, flux balance analysis

\section{Introduction}

With positive outcomes from medical treatments, biologics are one of the fastest growing drug groups in the pharmaceutical market, with monoclonal antibodies (mAbs) among the top five bestselling biologics (Aggarwal 2014). In order to increase the specific productivity of recombinant protein $\left(\mathrm{q}_{\mathrm{P}}\right)$, optimisation of industrial bioprocesses continues to be an important focus. The use of biphasic cultures involving a shift in temperature or $\mathrm{pH}$ is an approach to increase recombinant protein (rProtein) production yield. For example by reducing culture temperature from $37^{\circ} \mathrm{C}$ to $33^{\circ} \mathrm{C}$, Nam et al achieved a nearly 8 -fold increase in the specific productivity of recombinant secreted human placental alkaline phosphate (SEAP) in suspension Chinese hamster ovary (CHO) cell culture (Nam et al. 2008). A shift to mild hypothermic conditions $\left(30^{\circ} \mathrm{C}-34^{\circ} \mathrm{C}\right)$ has therefore become the very frequently employed industrial practice in rProtein production in $\mathrm{CHO}$ cell lines (Wulhfard et al. 2008). Not only does mild hypothermia affect rProtein productivity, it also slows down cell metabolism, reduces the rate of nutrient consumption and production of biological waste (Chuppa et al. 1997), causes the partial arrest of the cell population in G0/G1 phase of the cell cycle (Marchant et al. 2008), and stabilises transcriptional species as well as changing the efficiency of protein translation, folding and trafficking (Cain et al. 2013).

With an increasing demand for mAbs, research has led to tailoring of product quantity through mild hypothermia; however few investigations have been made into its effects on the glycosylation of the recombinant products. Regardless of the type of glycoprotein, the sugars attached contribute to protein folding, stability, trafficking, biological activity and serum clearance. In the case of $\operatorname{IgG}$, its Fc-domain controls the activation of downstream immune responses upon binding to Fc $\gamma$ receptors, 
where the ability of binding and the drug efficacy is influenced by the glycosylation pattern on the Fc-region. For instance, the absence of core-fucosylation results in the increase in AntibodyDependent Cell-Mediated Cytotoxicity (ADCC) activity by approximately 50-fold (Shinkawa et al. 2003), while terminal galactosylation increases Complement-Dependent Cytotoxicity (CDC) activity of $\mathrm{IgG}$ molecules through higher binding affinity of the mAbs to the $\mathrm{C} 1 \mathrm{q}$ complement molecules (Hodoniczky et al. 2005). The final glycan structure of the product is dependent on the expression levels and the activities of glycosyltransferases, as well as the availability of nucleotide sugar donors (NSDs), which are substrates of glycosyltransferases during glycan processing. NSD synthesis is highly influenced by the presence of key nutrients during cell culture (Murrell et al. 2004), e.g. glucose and galactose (Figure 1); as a result changes in cell metabolism during mild hypothermia can impact the glycosylation of the mAb. To ensure consistency in mAb quality, a thorough understanding of the relationships among cell metabolism, mAb synthesis and Fcglycosylation is necessary.

In this study, we examined the impact of mild hypothermia on an IgG-expressing CHO cell line and compared culture performance at different temperatures with respect to cell growth, metabolic profile (nutrients, biological wastes, amino acids and NSDs), mAb synthesis including heavy and light chain mRNA and assembly intermediates, as well as mAb glycan profiles and glycosyltransferase expression levels. We then performed flux balance analyses on data sets from both temperatures in order to generate a better understanding of the intracellular metabolic networks through calculating differences in metabolic flux changes upon the induction of mild hypothermia.

\section{Material and Methods}

\section{Cell line and maintenance}

An IgG-producing Chinese hamster ovary CHO-T cell line (MedImmune, Cambridge, UK) was revived and cultured in $\mathrm{CD}-\mathrm{CHO}$ medium (Life Technologies, Paisley, U.K.) where $50 \mu \mathrm{M}$ 
methionine sulfoximine (MSX) was supplemented during the first and second passages only, and was shaken at $140 \mathrm{rpm}$ in humidified $36.5^{\circ} \mathrm{C}$ incubator with $5 \% \mathrm{CO}_{2}$ supply. Cells were subcultured in fresh medium every three days at a seeding density of $3 \times 10^{5}$ viable cells $/ \mathrm{mL}$. Cell concentration and cell viability were measured by ViCell ${ }^{\circledR}$ (Beckman Coulter, CA, U.S.A.). Cells were transferred into the bioreactor system after 3 cell passages.

\section{Cell system and Operation}

Shake flasks were used in the culture of $\mathrm{CHO}$ cells prior to transfer into $1.5 \mathrm{~L}$ continuous- stirred tank DASGIP bioreactors (DASGIP Technology, Juelich, Germany) where each condition was examined in triplicate bioreactors. Each bioreactor contained an initial culture volume of $0.9 \mathrm{~L}$ with a starting viable cell density of $8 \times 10^{5}$ cells $/ \mathrm{mL}$. Within the 14-day cell culture period, the cultures were maintained at $\mathrm{pH} 6.9 \pm 0.1$ at $36.5^{\circ} \mathrm{C}$, or with a temperature shift to $32^{\circ} \mathrm{C}$ on day 6 post inoculation, with a stirring speed at $150 \mathrm{rpm}$ and $\mathrm{CO}_{2}$ air concentration at $5 \% \mathrm{v} / \mathrm{v}$. On days 2, 4, 6, 8,10 and 12 of the culture period, the cultures were supplemented with $10 \%$ by volume CD EfficientFeed $^{\mathrm{TM}} \mathrm{C} \mathrm{AGT}^{\mathrm{TM}}$ Nutrient supplement (Life Technologies, Paisley, U.K.) and $5 \mathrm{~mL}$ additions of $15 \%$ antifoam C (Sigma-Aldrich, Dorset, U.K.) were added when excessive foaming occurred.

\section{Analytical assays}

To determine the amount of intracellular metabolite, heavy and light chain mRNA and polypeptides that were produced throughout the experiments, $5 \times 10^{6}$ cells were collected for DNA/RNA quantification and $2 \times 10^{6}$ cells each for HC/LC mRNA, polypeptide and NSD analyses. Cells were centrifuged at $200 \mathrm{rpm}$ for 5 minutes in an Eppendorf microfuge, cell pellets were washed twice with PBS. Clarified supernatants were used to determine extracellular nutrient and secreted mAb concentrations. Both pellets and supernatant samples were stored at $-80^{\circ} \mathrm{C}$.

\section{(a) Nutrients, metabolites and secreted mAb concentrations}


Extracellular concentrations of glucose, lactate and ammonia in supernatant samples were determined using the YSI Bioprofiler 800 (NOVA Biomedical, MA, U.S.A.). Extracellular amino acid quantification was performed with a Waters Acquity ultra-performance liquid chromatography (UPLC, Waters, Hertfordshire, U.K.) using the AccQ-tag kit according to the manufacturer's instructions. Secreted mAb titre was determined using a Protein-A affinity chromatography method.

\section{(b) DNA and RNA extraction and cDNA preparation}

The total DNA and RNA of each sample was extracted from cell pellets using the All prep DNA/RNA mini purification kit (Qiagen, Manchester, U.K.) as described in the manufacturer's instructions. $300 \mathrm{ng}$ of extracted RNA from each sample was reversed transcribed into cDNA using $1 \mu \mathrm{L}$ of the RT Primer Mix of the QuantiTect Reverse Transcription Kit (Qiagen, Manchester, U.K.).

\section{(c) mAb heavy and light chain, glycosyltransferase mRNA measurement}

mRNA expression levels of mAb heavy (HC HuG1) and light chains (LC HuKappa) in each sample were quantified by quantitative real-time polymerase chain reaction (qRT-PCR). Each sample was analysed in triplicate PCR reactions. A total of $10 \mu \mathrm{L}$ of reaction volume was used per sample in a 96 well-plate, with $5 \mu \mathrm{L}$ of 2x SYBR Green Supermix (Sigma-Aldrich, Dorset, U.K.), $0.64 \mu \mathrm{L}$ of cDNA and $500 \mathrm{nM}$ of each primer. Non-template controls were carried out for each PCR reaction. PCR reactions were initiated with 3 min at $95^{\circ} \mathrm{C}$ for SYBR Green activation; followed by 40 cycles of $95^{\circ} \mathrm{C}$ for $30 \mathrm{~s}, 60^{\circ} \mathrm{C}$ for $75 \mathrm{~s}$ and $72^{\circ} \mathrm{C}$ for $30 \mathrm{~s}$. The product integrity was verified by the DNA melting curve from $65^{\circ} \mathrm{C}$ to $95^{\circ} \mathrm{C}$ (read every $0.3^{\circ} \mathrm{C}$ ). Results were compared to the $\mathrm{C}_{\mathrm{t}}$-number of a house-keeping $\beta$-actin gene for relative analysis. Primer sequences are available on request.

\section{(d) Determination of heavy and light chain mRNA half-lives}

To estimate the stability of heavy and light chain mRNA molecules, duplicate shake flask experiments were performed at both $36.5^{\circ} \mathrm{C}$ and $32^{\circ} \mathrm{C}$. At late exponential phase (day 6) of each culture, $65 \mu \mathrm{M}$ of the transcription inhibitor DRB (5,6 dichloro-1 $\beta$-D-ribofuranosyl 
benzinmidazole, Sigma-Aldrich, Dorset, U.K.) dissolved in 100\% ethanol (VWR, Lutterworth, U.K.) was added to block cell transcription. The same volume of ethanol was added to the control cultures at both temperatures to compensate for the effect of ethanol on the cells. $5 \times 10^{6}$ cells $/ \mathrm{mL}$ were collected from each culture at $0,3,6,9,12$ hours after the inhibitor/ethanol additions. Transcribed cDNA from each sample were quantified by qRT-PCR. Results were normalized to a standard curve generated with known amounts of the $\mathrm{HC} / \mathrm{LC}$ plasmids and their respective $\mathrm{C}_{\mathrm{t}^{-}}$ values. mRNA levels were determined from their respective standard curves and decay rates were calculated.

\section{(e) Intracellular mAb polypeptides and assembly intermediate analysis}

Cell pellets with $2 \times 10^{6}$ viable cells were washed with $\mathrm{PBS}$ at $4^{\circ} \mathrm{C}$ to remove any supernatant residue. The PBS was aspirated and cell pellets were resuspended in $125 \mu \mathrm{L}$ of CellLytic ${ }^{\mathrm{TM}} \mathrm{M}$ solution (Sigma-Aldrich, Dorset, U.K.) supplemented with $1 \%(\mathrm{v} / \mathrm{v})$ protease inhibitor cocktail (Sigma-Aldrich, Dorset, U.K.). Mixtures were incubated at room temperature on an orbital shaker for $15 \mathrm{~min}$. The lysates were spun at $18,000 \mathrm{x} \mathrm{g}$ for $15 \mathrm{~min}$. The protein-containing supernatant was stored at $-80^{\circ} \mathrm{C}$ prior to Western blot analysis. $4 \mu \mathrm{L}$ of $4 \mathrm{x}$ NuPAGE sample buffer was added to 12 $\mu \mathrm{L}$ of each sample and 100,10, 1 and $0.1 \mu \mathrm{g}$ of purified $\mathrm{IgG}$ controls (provided by MedImmune, Granta Park, Cambridge, U.K.). Each sample was run on $12 \%$ Precast Protein gel (Thermo Scientific, Horsham, U.K.) in Tris-HEPES running buffer at $120 \mathrm{~V}$ for $1 \mathrm{~h}$. The polyacrylamide gel was washed twice with $\mathrm{dH}_{2} \mathrm{O}$ before being transferred in a semi-dry transfer system (Bio-Rad, Hertfordshire, U.K.) onto a methanol-activated PVDF transfer membrane (Millipore, Watford, U.K.) at $0.3 \mathrm{~A}$ for $50 \mathrm{~min}$. After successful transfer, 1:1000 horseradish peroxidase (HRP)conjugated goat anti-human IgG Fc primary antibody (Jackson Immunoresearch, PA, U.S.A.) was used as the primary antibody and visualisation proceeded with the WesternBreeze ${ }^{\circledR}$ Chemiluminescent Anti-Goat-Kit (Life Technologies, Paisley, U.K.) according to the manufacturer's instructions and using a 10 min exposure time (FujiFilm, Bedford, U.K.). The 
intensity of each band was quantified using MYImageAnalysis Software Manual (Thermo Scientific, Horsham, U.K.) and concentrations were determined through comparison to the IgG protein standard.

\section{(f) Analysis of galactosyltransferase III (GalTIII) protein expression}

$2 \times 10^{6}$ viable cell pellets were rinsed with $4^{\circ} \mathrm{C}$ PBS prior to cell lysis in $200 \mu \mathrm{L}$ of M-PER Mammalian protein extraction reagent (Thermo Scientific, Horsham, U.K.) supplemented with 1\% (v/v) protease inhibitor cocktail (Sigma-Aldrich, Dorset, U.K.). Sampled were gently shaken for 10 min before they were sonicated at 3 burst of 5 seconds on ice, with 25 seconds intervals and an amplitude power of 20. Cell debris was removed by centrifugation at $14,000 \mathrm{x} \mathrm{g}$ for $15 \mathrm{~min}$. Membrane protein-containing supernatant was stored at $-80^{\circ} \mathrm{C}$ prior to Western blot analysis as described in (e), with an exception of $10 \mathrm{~min} 100^{\circ} \mathrm{C}$ sample incubation before gel electrophoresis. $\beta-1,4-G a l-T 3$ Antibody (N20) (Santa Cruz Biotechnology, Texas, USA) was used as primary antibody for western blotting and protein concentration in each sample was compared to known concentrations of $\beta-1,4-G a l-T 3$ (N20) blocking peptide (Santa Cruz Biotechnology, Texas, USA).

\section{(g) Extraction of intracellular NSD and analysis}

Intracellular nucleotide sugars were extracted by an acetonitrile extraction method (Dietmair et al. 2010; Viant et al. 2005). In brief, $400 \mu \mathrm{L}$ of ice cold 50\% v/v aqueous acetonitrile was added to a cell pellet containing $2 \times 10^{6}$ cells. The mixture was incubated on ice for $10 \mathrm{~min}$ before centrifugation at $18,000 \mathrm{xg}$ for $5 \mathrm{~min}$ at $0^{\circ} \mathrm{C}$. Supernatant was dried thoroughly using a SpeedVac (Savant Inc. Laboratory, MI, U.S.A.). Dried samples were resuspended in $150 \mu \mathrm{L}$ of deionised water and were filtered by $0.2-\mu \mathrm{m}$ syringe filter units (Fisher Scientific, Loughborough, U.K.) before HPAEC analysis. The NSD analytic method was based on del Val et al. (2013), using a CarboPac PA-1 column with a PA-1 guard column (Dionex, CA, USA). Elution of samples was done using a gradient of $\mathrm{E} 1(3 \mathrm{mM} \mathrm{NaOH})$ and $\mathrm{E} 2(1.5 \mathrm{mM}$ sodium acetate in $3 \mathrm{mM} \mathrm{NaOH})$ buffers as mobile phases. Detection of all species was carried out at two absorbance wavelengths: 
$271.6 \mathrm{~nm}$ for all cysteine-bearing species and $262.1 \mathrm{~nm}$ for the rest of all other compounds. This method was capable to resolve 10 nucleotides - ATP, CTP, GTP, UTP, AMP, ADP, CMP, GMP, UMP and UDP, as well as 9 nucleotide sugar compounds o CMP-Neu5Ac, UDP-GalNAc, UDPGlcNAc, UDP-Gal, UDP-Glc, GDP-Fuc, GDP-Man, GDP-Glc and UDP-GlcA.

\section{(h) mAb glycan analysis}

Purified mAb samples with concentration range of $1.25-7.5 \mathrm{mg} / \mathrm{mL}$ were prepared for glycan analysis using the ProfilerPro Glycan Profiling Kit (PerkinElmer, MA, U.S.A.). $8 \mu$ L of samples were firstly denatured in the Denaturing Plate containing $3 \mu \mathrm{L}$ of denaturing solution for 10 min at $70^{\circ} \mathrm{C} .11 \mu \mathrm{L}$ of denatured materials were next transferred to Peptide-N-Glycosidase F (PNGase F) Plate and was incubated at $37^{\circ} \mathrm{C}$ for $1 \mathrm{~h}$ to separate glycan from the protein. $8 \mu \mathrm{L}$ of the digested samples were transferred to the Labelling Plate and was incubated at $55^{\circ} \mathrm{C}$ for $2 \mathrm{~h}$ for glycan labelling. Dried samples were reconstituted in $100 \mu \mathrm{L}$ of molecular grade water and glycan analysis was performed by the LabChip ${ }^{\circledR}$ GXII instrument (PerkinElmer, MA, U.S.A.).

\section{Flux balance analysis (FBA)}

The R workspace (R Development Core Team 2010) and the Sybil package (Gelius-Dietrich et al. 2013) were used to perform the FBA. The metabolic network was constructed by Kyriakopoulos and Kontoravdi (2014) based on the network proposed by Carinhas et al. (2013). The biomass composition used was that proposed by Selvarasu et al. (2012) for CHO cells, but excluding Cys. The final model consisted of 120 metabolites, 97 intracellular reactions and 57 transport equations, as shown in the Supplementary Table 2. The model was optimised by assuming maximum biomass and $\operatorname{IgG}$ accumulation during exponential phase, and maximum $\operatorname{IgG}$ accumulation at stationary phase. FBA was conducted based on the experimentally measured concentrations of extracellular amino acids, glucose, lactate, ammonia and viable cell density and $\operatorname{IgG}$ titres. The upper and lower limits were set within 1 standard deviation while the remaining extracellular fluxes were set at $\pm 20 \%$ (Carinhas et al. 2013). Choline was included in the network to account for lipid synthesis. In 
order to examine the glucose fluxes to nucleotide and NSD production for glycosylation, GlcNAc, GalNAc, Mann, Fuc, Gal and Neu5Gc were added in the biomass equation. The amount of each NSD necessary for host cell protein glycosylation, was estimated based on the results from the MS glycan study in Stanley (2010), as well as the occurring frequency of N- and O-linked glycans based on Apweiler et al. (1999). These data were then used to calculate the respective stoichiometric coefficients (mmol per gram of dry cell weight, mmol/gDCW) that were incorporated in the biomass equation and used in the FBA analysis.

\section{Results}

\section{CHO cell culture behaviour and mAb production profile during mild hypothermia}

Two sets of experiments were carried out to investigate the impact of mild hypothermia: 14-day $\mathrm{CHO}$ cell fed-batch culture at $36.5^{\circ} \mathrm{C}$ or with a temperature shift from $36.5^{\circ} \mathrm{C}$ to $32^{\circ} \mathrm{C}$ on day 6 at late exponential phase. Figures 2A and B show the growth profiles of $\mathrm{CHO}$ cell cultures and their specific mAb productivities at both temperatures. When compared to culture at $36.5^{\circ} \mathrm{C}$, cells that were temperature-shifted to $32^{\circ} \mathrm{C}$ maintained a high viability of $98.2 \%$ on harvest day with only a $10.0 \%$ reduction in their integral viable cell concentration (IVCC). Accompanied with increased cell viability, a $46.2 \%$ rise in the specific mAb productivity was observed. To better elucidate the increase in $\mathrm{q}_{\mathrm{mAb}}$ at lower temperature, intracellular species produced in the mAb synthesis process were experimentally quantified. Results show that only the heavy chain mRNA expression level was higher at $32^{\circ} \mathrm{C}$ (Figures $3 \mathrm{~A}$ and $\mathrm{B}$ ), while at a translational level the overall concentrations of $\mathrm{H}_{2}$ and $\mathrm{H}_{2} \mathrm{~L}$ mAb assembly intermediates increased upon temperature shift (Figures 3C and D). In both mRNA and polypeptide concentrations, our results suggest the heavy chain to be the ratedetermining species for $\mathrm{mAb}$ synthesis, with the increase in $\mathrm{HC}$ mRNA transcripts at $32^{\circ} \mathrm{C}$ being advantageous for overall mAb production (Figure 3E). This is in good agreement with findings of O'Callaghan et al. (2010) where they concluded that $\mathrm{q}_{\mathrm{mAb}}$ was controlled mostly by the rate of HC 
translation. In addition, a lower culture temperature was shown to stabilise both HC and LC mRNA, with $14 \%$ and $22 \%$ reductions in $\mathrm{HC}$ and LC mRNA decay rates (Table 1), respectively.

\section{The impact of mild hypothermia on nucleotide sugar donor synthesis and $\mathbf{m A b}$ glycosylation}

To ensure product quality, the final secreted mAb Fc-glycan profile was analysed on days 8, 10, 12 and 14 for both temperatures. With respect to time, the terminal glycan structures observed in harvest products were comparable to those on days 8,10 and 12 . With mild hypothermia, alongside with the increased in $\mathrm{mAb}$ protein titre, we observed a significant increase in the proportion of $\operatorname{IgG}$ molecules with underprocessed glycan structures, approximately $3 \%$ and $17 \%$ increase in G0 and G0F, respectively and also $15 \%$ and $3 \%$ reduction in the fraction of the more processed glycoforms namely G1F and G2F, respectively on day 12 (Figure 4A).

Murrell et al. (2004) demonstrated the complexity of the intracellular NSD synthetic pathway, where the type of sugar source (glucose, galactose, mannose etc.) and their uptake rate affected the production of nucleotide sugars, the building components for protein glycosylation. The availability of glutamine in the system was also critical for nucleotide synthesis. Quantification of the intracellular NSD concentrations was therefore a useful approach to understand the relationship between $\mathrm{CHO}$ cell metabolism and product glycosylation. UDP-Glc is essential in the initiation of $\mathrm{N}$-linked glycosylation due to its role in dolichol-linked precursor oligosaccharide $\left(\mathrm{GlcNAc}_{2} \mathrm{Man}_{9} \mathrm{Glc}_{3}\right)$ generation in the ER lumen. The intracellular concentration of UDP-Glc remained similar at exponential phases. However, in part due to reduced consumption of glucose during mild hypothermia, the amounts of UDP-Glc, UDP-Gal and UDP-GlcNAc (essential for glycan branching and elongation) within the cells decreased upon temperature shift (Figures 4 B-D). Impact of mild hypothermia on expression of genes related to $\mathrm{N}$-glycosylation

From the glycan analysis we observed an increase in the underprocessed glycan structures in the secreted $\mathrm{mAb}$ produced at $32^{\circ} \mathrm{C}$. In addition to cell metabolic adjustments induced by mild hypothermia where it affected the availability of key NSDs for mature glycoform formation, 
expression of proteins that are involved in N-linked glycosylation could be temperature sensitive. Thus, we investigated the mRNA expression levels of 6 NSD glycosyltransferase enzymes, namely $2 \mathrm{~N}$-acetylglucosaminyltransferases (GnTI and GnTII) which are involved in glycan branching, 3 galactosyltransferases ( $\beta$-GalTI, II and III) and fucosyltransferase (FucT) that adds GDP-Fuc onto the $\mathrm{N}$-glycan core in IgG. In addition, we examined the mRNA expression levels of 2 transporters: UDP-Gal and UDP-GlcNAc transporters, responsible for exchanges of their respective NSDs between the Golgi apparatus and the cell cytosol. Figure 5A describes the transcript expression profiles at both temperatures. The glycosyltransferases GnTII, GalTI, GalTIII, and FucT showed significantly lower mRNA expression levels at $32^{\circ} \mathrm{C}$. Overall, GnTI, GalTII and the two transporters examined did not show significant variation in their expression levels, apart from a drop in mRNA level of UDP-GlcNAc $\mathrm{T}$ at day 14 of the mild hypothermic cultures. The downregulation of GalTIII gene expression observed at $32^{\circ} \mathrm{C}$ was further supported by the reduction in $\beta-1,4-$ GalT-III protein expression in cells cultured in mild hypothermic condition (Figure 5B).

\section{The impact of mild hypothermia on CHO cell metabolism through flux balance analysis and experimental studies}

Prompted by the reduction in NSD availability observed at $32^{\circ} \mathrm{C}$, flux balance analysis (FBA) was applied to understand how lower culture temperature impacted on $\mathrm{CHO}$ cell metabolism. Prior to performing the FBA, the consumption and production rates of each exometabolite measured were calculated with the rate calculation code of (Kyriakopoulos 2014). Table 2 shows the calculated production and consumption rates of each exometabolite during the two phases at both temperatures. The overall amino acid and glucose exchanges from the extracellular environment were higher at exponential than at stationary phase. By comparing the two temperatures at stationary phase, we can see there was a reduction in the consumption rates of metabolites at $32^{\circ} \mathrm{C}$, together with a shift from lactate production to consumption which correlated well with 
experimental data. The rate of $\mathrm{IgG}$ production was also higher at $32^{\circ} \mathrm{C}$. The $\mathrm{FBA}$ was then constrained with the rates of exometabolites, maximum $\mathrm{q}_{\mathrm{mab}}$ and growth rate $(\mu)$ during exponential (days 3-6) growth, but maximum $\mathrm{q}_{\mathrm{mab}}$ and exometabolite uptake/production rates only at late exponential/stationary phase (days 7-10). Results from the FBA (Figure 6) showed that during exponential growth the flux of glucose entering the TCA cycle through glycolysis was less than that during stationary phase, when there was increased storage of carbon as glycogen and higher fluxes out from the TCA into biomass, $\mathrm{IgG}$, amino acid and energy generations to sustain cell growth at exponential growth. At $36.5^{\circ} \mathrm{C}$, the flux of glucose from glycolysis to the TCA during stationary phase increased and the TCA cycle was more efficient, with reduced flow of species toward biomass/IgG production. However, when mild hypothermia was induced, lactate became the main fuel for the TCA cycle, with no carbon loss to glycogen production. This metabolic shift from glucose to lactate was supported by the dramatic drop of extracellular lactate concentration observed experimentally (Figure 7B).

While most of the product generated from glycolysis was consumed within the TCA cycle at $36.5^{\circ} \mathrm{C}$, at $32^{\circ} \mathrm{C}$ less energy was spent on the TCA cycle, the consumption of glutamate was higher, where glutamate fluxes towards glutamine and aspartate syntheses increased with mild hypothermia, which contributed to the increase in IgG production. Moreover, the conversion rate from glucose-6-phosphate into ribulose-5phosphate (R5P) and NADPH was 21 times lower at $32^{\circ} \mathrm{C}$. This contributed to reduced synthetic rates of nucleotide, NSD and lipids. Supplementary Table 3 illustrates the lower fluxes of carbon and energy sources entering into all the three synthetic pathways at $32^{\circ} \mathrm{C}$, accompanied by increase production of glutamine and a high exchange rate of glutamine from the cell cytosol to the extracellular environment. In addition, the synthesis of hexosamines (GlcNAc, GalNAc) requires glutamine and a reduced flux of glutamine into nucleotide/NSD synthesis was suggested by the FBA, which caused the drop of UDP-GlcNAc concentration that was measured experimentally. 
Through experiments, $\mathrm{CHO}$ cells were shown to be metabolically less active when the temperature was lowered to $32^{\circ} \mathrm{C}$ at late exponential phase. Glucose was the main carbon source in the cultures and at $32^{\circ} \mathrm{C}$ we observed a reduction in glucose consumption, reflected by the higher extracellular glucose concentration in Figure 7A. This coincided with the estimation from the FBA where less glucose entered into glycolysis. On the other hand, cells achieved an increase in extracellular ammonia level upon temperature shift (days 6-10) but it levelled out with the concentration obtained at $36.5^{\circ} \mathrm{C}$ on day 10 , when most $\mathrm{NH}_{4}$ was consumed to generate glutamine (Figure $7 \mathrm{C}$ ).

\section{Discussion}

The adaptations that $\mathrm{CHO}$ cells undergo in response to mild hypothermia have led to significant changes in the productivity and the glycoform composition of the mAb. The prolonged cell viability that we observed in this study could be explained by the work of Marchant et al. (2008) which demonstrated that cells experienced a partial cell cycle arrest upon mild hypothermia. Instead of dividing cells for high cell density, more energy was generated within the TCA to sustain other intracellular activities, such as mAb protein synthesis and trafficking.

As expected, at exponential growth, higher proportions of energy and amino acids were consumed for biomass formation, while reduced consumption towards cell growth was observed at stationary phase. During mild hypothermia, there was an increased net flux of amino acids into IgG protein synthesis, which was illustrated by a $46.2 \%$ rise in the rate of mAb production. As a result of slower cell metabolism, more energy is likely to have been channelled towards protein production, which could have consequently led to reduced inputs towards protein glycosylation.

In addition, the reduced consumption of glucose that was experimentally observed was mirrored by a lowered influx of extracellular glucose into glycolysis shown in our FBA, where a metabolic shift to lactate consumption was triggered by the reduced production of NADH. This was to maintain the TCA cycle efficiency during stationary phase. However, the synthesis of nucleotides and nucleotide 
sugars relied on the availability of glucose and glycolysis species namely glucose-6-phosphate and fructose-6-phosphate, together with R5P generated from the pentose-phosphate pathway, which is fuelled from glycolysis. The reduced metabolic rates in these pathways resulted in lower synthetic rates of the glycosylation substrates. Since the transcript expression of GnTII, GalTs and FucT were shown to be lower under mild hypothermia, accompanied by reduced GalT protein expression at $32^{\circ} \mathrm{C}$, decrease in NSD synthesis, UDP-GlcNAc and UDP-Gal in particular, together with lower glycosyltransferase expression levels restrict the formation of bi-antennary and more complicated glycan profiles which require terminal galactosylation.

In addition, lipid synthesis relies on availability of G6P, AcCoA and various amino acids. The decrease in lipid synthesis calculated by the FBA could affect the generation of cell membranes and transport vesicles, which are important in the embedment for nucleotide-sugar transporters into the lipid bilayers.

By combining experimental data with the FBA approach, we managed to draw a relationship among the increase in $\mathrm{mAb}$ synthesis, the deceleration in cell metabolism and reduced maturation of $\mathrm{mAb}$ glycan structures during mild hypothermia. Figure 8 provides an overview of how mAb glycosylation can be influenced by lowering culture temperature. The low metabolic state of cells reduced NSD synthesis as well as glycosyltransferase expression, GalT in particular, which directly impacted on the process of protein glycosylation. Under mild hypothermic condition, a higher proportion of energy and amino acid consumptions were used for product formation than NSD synthesis. By exploring this relationship, it may be possible to predict changes in glycan structure based on the effects of different bioprocess conditions on cell metabolism, as well as developing improved feeding strategies to target specific glycan patterns.

\section{Concluding remarks}

This study explored the impact of mild hypothermia on mAb N-glycosylation, by examining changes in cell metabolism and IgG synthesis experimentally and computationally through flux 
balance analysis. We observed a slow-down in cell metabolism but an increase in recombinant IgG production when mild hypothermia was induced at stationary phase. The product quality, however, was influenced by culture temperature, with a higher fraction of the under-processed glycan structures found in the secreted $\operatorname{IgG}$ produced at $32^{\circ} \mathrm{C}$. The relationship among a reduced cell metabolic rate, an increased $\operatorname{IgG}$ titre and the variation in product glycosylation was better established through the use of the FBA. Estimated fluxomes revealed an overall lower cell metabolism at $32^{\circ} \mathrm{C}$ during stationary phase, together with decreased fluxes of carbon, energy and glutamine into nucleotide and NSD synthesis. More energy and metabolites were also estimated to contribute to a higher mAb productivity (Yoon et al. 2006), which further restricted resources that were necessary for $\mathrm{mAb}$ glycosylation. Furthermore, expression levels of key enzymes for N-linked glycan branching and elongation was downregulated, this in part contributed to the generation of pre-matured glycan structures in the secreted product. Our study allowed better clarification on the behaviours of $\mathrm{CHO}$ cells in mild hypothermia and demonstrated its impact on mAb Fcglycosylation, which will be beneficial for future design of experiment.

\section{Acknowledgement}

SNS thankfully acknowledges the Biotechnology and Biological Sciences Research Council and Bioprocessing Research Industry Club for her studentship. The financial contribution of MedImmune plc is gratefully acknowledged. The authors thank Kalpana Nayyar, Andrew Smith and Neil Birkett for their assistance in glycan, mAb titre analyses and mAb purification, respectively. KMP and CK thank Research Councils U.K. for their fellowships. CK thanks Lonza Biologics for their financial support. 


\section{References}

Aggarwal S. 2014. What's fueling the biotech engine[mdash]2012 to 2013. Nat Biotech 32(1):32-39.

Apweiler R, Hermjakob H, Sharon N. 1999. On the frequency of protein glycosylation, as deduced from analysis of the SWISS-PROT database. Biochim Biophys Acta 1473(1):4-8.

Cain K, Peters S, Hailu H, Sweeney B, Stephens P, Heads J, Sarkar K, Ventom A, Page C, Dickson A. 2013. A CHO cell line engineered to express XBP1 and ERO1-Lalpha has increased levels of transient protein expression. Biotechnol Prog 29(3):697-706.

Carinhas N, Duarte TM, Barreiro LC, Carrondo MJ, Alves PM, Teixeira AP. 2013. Metabolic signatures of GS-CHO cell clones associated with butyrate treatment and culture phase transition. Biotechnology and Bioengineering 110(12):3244-57.

Chuppa S, Tsai YS, Yoon S, Shackleford S, Rozales C, Bhat R, Tsay G, Matanguihan C, Konstantinov K, Naveh D. 1997. Fermentor temperature as a tool for control of high-density perfusion cultures of mammalian cells. Biotechnol Bioeng 55(2):328-38.

del Val IJ, Kyriakopoulos S, Polizzi KM, Kontoravdi C. 2013. An optimized method for extraction and quantification of nucleotides and nucleotide sugars from mammalian cells. Anal Biochem 443(2):172-80.

Dietmair S, Timmins NE, Gray PP, Nielsen LK, Kroemer JO. 2010. Towards quantitative metabolomics of mammalian cells: Development of a metabolite extraction protocol. Analytical Biochemistry 404(2):155-164.

Gelius-Dietrich G, Desouki AA, Fritzemeier CJ, Lercher MJ. 2013. sybil - Efficient constraint-based modelling in R. BMC Syst Biol 7(1):125.

Hodoniczky J, Zheng YZ, James DC. 2005. Control of recombinant monoclonal antibody effector functions by Fc N-glycan remodeling in vitro. Biotechnol Prog 21(6):1644-52.

Kyriakopoulos S. 2014. Amino acid metabolism in Chinese hamster ovary cell culture. London, U.K.: Imperial College London.

Kyriakopoulos S, Kontoravdi C. 2014. A framework for the systematic design of fed-batch strategies in mammalian cell culture. Biotechnol Bioeng.

Marchant RJ, Al-Fageeh MB, Underhill MF, Racher AJ, Smales CM. 2008. Metabolic rates, growth phase, and mRNA levels influence cell-specific antibody production levels from in vitrocultured mammalian cells at sub-physiological temperatures. Molecular biotechnology 39(1):69-77.

Murrell MP, Yarema KJ, Levchenko A. 2004. The systems biology of glycosylation. Chembiochem 5(10):1334-47.

Nam JH, Zhang F, Ermonval M, Linhardt RJ, Sharfstein ST. 2008. The effects of culture conditions on the glycosylation of secreted human placental alkaline phosphatase produced in Chinese hamster ovary cells. Biotechnol Bioeng 100(6):1178-92.

O'Callaghan PM, McLeod J, Pybus LP, Lovelady CS, Wilkinson SJ, Racher AJ, Porter A, James DC. 2010. Cell line-specific control of recombinant monoclonal antibody production by $\mathrm{CHO}$ cells. Biotechnol Bioeng 106(6):938-51.

R Development Core Team. 2010. R: A language and environment for statistical computing. Austria.

Selvarasu S, Ho YS, Chong WPK, Wong NSC, Yusufi FNK, Lee YY, Yap MGS, Lee DY. 2012. Combined in silico modeling and metabolomics analysis to characterize fed-batch $\mathrm{CHO}$ cell culture. Biotechnology and Bioengineering 109(6):1415-1429.

Shinkawa T, Nakamura K, Yamane N, Shoji-Hosaka E, Kanda Y, Sakurada M, Uchida K, Anazawa H, Satoh $M$, Yamasaki $M$ and others. 2003. The absence of fucose but not the presence of galactose or bisecting $\mathrm{N}$-acetylglucosamine of human IgG1 complex-type oligosaccharides shows the critical role of enhancing antibody-dependent cellular cytotoxicity. J Biol Chem 278(5):3466-73.

Stanley P. 2010. Structural data for the community on the popular $\mathrm{CHO}$ mutant cell lines. Functional Glycomics Gateway. 
Viant M, Bundy J, Pincetich C, de Ropp J, Tjeerdema R. 2005. NMR-derived developmental metabolic trajectories: an approach for visualizing the toxic actions of trichloroethylene during embryogenesis. Metabolomics 1(2):149-158.

Wulhfard S, Tissot S, Bouchet S, Cevey J, De Jesus M, Hacker DL, Wurm FM. 2008. Mild hypothermia improves transient gene expression yields several fold in chinese hamster ovary cells. Biotechnology Progress 24(2):458-465.

Yoon SK, Kim SH, Song JY, Lee GM. 2006. Biphasic culture strategy for enhancing volumentric erythropoietin productivity of Chinese hamster ovary cells. Enzyme and Microbial Technology 39(3):362-365. 


\section{Table captions}

Table 1. Overview of heavy and light chain mRNA stability at $36.5^{\circ} \mathrm{C}$ and with temperature-shifted to $32^{\circ} \mathrm{C}$ on day 6 .

Table 2. Average specific metabolic production and consumption rates for $36.5^{\circ} \mathrm{C}$ and with temperature-shifted to $32^{\circ} \mathrm{C}$ on day 6 . Average rates were calculated from 6 sets and 3 sets of experimental data that was carried out at $36.5^{\circ} \mathrm{C}$ and with temperature shift, respectively. All species are shown in femtolmol/cell/day except $\mu$ which has units of 1/day. Exponential phase: days 3-6; stationary phase: days7-10. Negative value indicates consumption. TS: Temperature shift. 


\section{Figure legends}

Figure 1. NSD biosynthetic pathway in mammalian cells. Raw materials that are required for NSD metabolism are sugar residues: glucose (Glc), galactose (Gal), glucosamine (GlcN), fucose (Fuc) and mannose (Man), as well as nucleotide-precursors. NSD products are transported in the ER or the Golgi for protein glycosylation. Figure modified from Murrell MP et al. 2004) [9].

Figure 2. Cell growth and specific productivity $\left(\mathrm{q}_{\mathrm{mAb}}\right)$ of secreted $\operatorname{IgG}$ at $36.5^{\circ} \mathrm{C}$ and with a temperature shift to $32^{\circ} \mathrm{C}$. Viable cell concentration and cell viability profiles were measured along the period of cell culture (A), together with the $\mathrm{q}_{\mathrm{mAb}}(\mathbf{B})$ which was calculated based on terminal secreted product, and accumulated mAb concentration profile (C) of both temperatures. Results were average measurements from 6 experimental data sets at $36.5^{\circ} \mathrm{C}(\mathrm{n}=6)$ and 3 data sets at $32^{\circ} \mathrm{C}$ $(n=3)$. The error bars represent the standard deviation of the six- and triplicate samples in two cases. TS: Temperature shift.

Figure 3. Concentration profiles of heavy (A) and light chain (B) mRNA and H2 (C), H2L (D) intracellular assembly intermediates of $\operatorname{IgG}$ molecules at $36.5^{\circ} \mathrm{C}$ and $32^{\circ} \mathrm{C}$ TS. The overlay profiles of $\mathrm{HC}$ mRNA copy number, accumulated $\mathrm{mAb}$ and $\mathrm{H}_{2}$ concentrations (E) suggested heavy chain to be rate determining species in mild hypothermic condition. Results were average measurements from 6 experimental data sets at $36.5^{\circ} \mathrm{C}(\mathrm{n}=6)$ and 3 data sets at $32^{\circ} \mathrm{C}$ TS $(n=3)$. The error bars represent the standard deviation of the six- and triplicate samples in two cases. TS: Temperature shift.

Figure 4. Glycan and NSD profile of the secreted IgG. Fractions of 6 glycan structures (A): Man5, G0, G0F, G1F, G2 and G2F on the secreted IgG products were determined, together with concentrations of UDP-Glc (B), UDP-GlcNAc (C) and UDP-Gal (D) that were experimentally measured. Results were average measurements from 6 experimental data sets at $36.5^{\circ} \mathrm{C}(\mathrm{n}=6)$ and 3 data sets at $32^{\circ} \mathrm{C}$ TS $(n=3)$. The error bars represent the standard deviation of the six- and triplicate 
samples in two cases. Statistical significance was calculated and was represented by: $p \unlhd 0.05(*)$, $p \leq 0.01(* *)$ and $p \leq 0.001(* * *)$. TS: Temperature shift.

Figure 5. Expression profile of protein N-linked glycosylation enzymes (A) and relative difference in galactosyltransferase III (GalTIII) protein expression (B). Results were average measurements from 6 experimental data sets at $36.5^{\circ} \mathrm{C}(\mathrm{n}=6)$ and 3 data sets at $32^{\circ} \mathrm{C}$ TS $(n=3)$. The error bars represent the standard deviation of the six- and triplicate samples in two cases. Statistical significance was calculated and was represented by: $p \leq 0.05(*), p \leq 0.01\left(^{* *}\right)$ and $p \leq 0.001(* * *)$.TS: Temperature shift.

Figure 6. Central carbon metabolism of $\mathrm{CHO}$ cells at exponential growth (days 3-6), stationary phase (days $7-10$ ) at $36.5^{\circ} \mathrm{C}$ and stationary phase coupled with mild hypothermia. Thickness of an arrow indicates the relative flow of the carbon source within the system. This figure is simplified to include carbon lost to glycerol, glycogen and lactate production, together nucleotide, NSD, lipid and key amino acid synthesis.

Figure 7. Overview of extracellular metabolite concentrations. Concentration profiles of extracellular glucose (A), lactate (B) and ammonia (C) when $\mathrm{CHO}$ cells were culture at $36.5^{\circ} \mathrm{C}$ or under mild hypothermia at $32^{\circ} \mathrm{C}$ introduced on day 6 . Results were average measurements from 6 experimental data sets at $36.5^{\circ} \mathrm{C}(\mathrm{n}=6)$ and 3 data sets at $32^{\circ} \mathrm{C}(\mathrm{n}=3)$. The error bars represent the standard deviation of the six- and triplicate samples in two cases. TS: Temperature shift.

Figure 8. An overview of the impact of mild hypothermia on mAb glycosylation. 
Figure 1. NSD biosynthetic pathway in mammalian cells. Raw materials that are required for NSD metabolism are sugar residues: glucose (Glc), galactose (Gal), glucosamine (GlcN), fucose (Fuc) and mannose (Man), as well as nucleotide-precursors. NSD products are transported in the ER or the Golgi for protein glycosylation. Figure modified from Murrell MP et al. 2004) [9]. $209 \times 148 \mathrm{~mm}(300 \times 300$ DPI $)$ 
1

2

3

4

5

6

7

8

9

10

11

12

13

14

15

16

17

18

19

20

21

22

23

24

25

26

27

28

29

30

31

32

33

34

35

36

37

38

39

40

41

42

43

44

45

46

47

48

49

50

51

52

53

54

55

56

57

58

59

60
A.

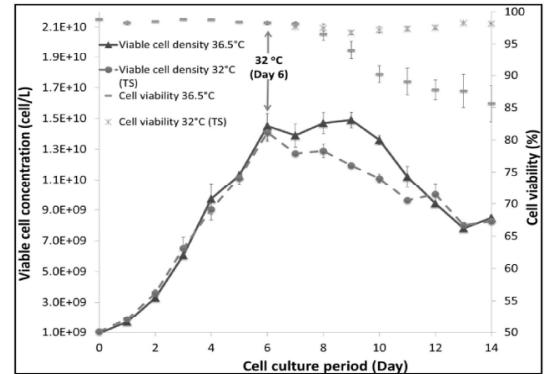

B.

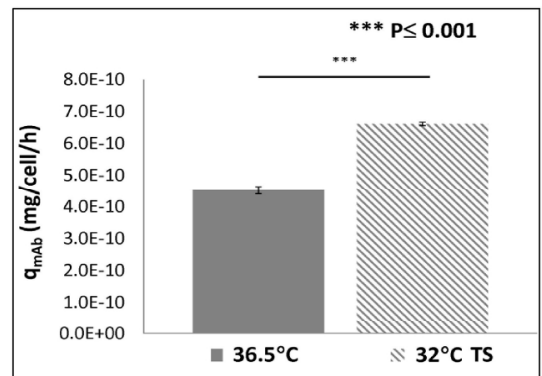

c.

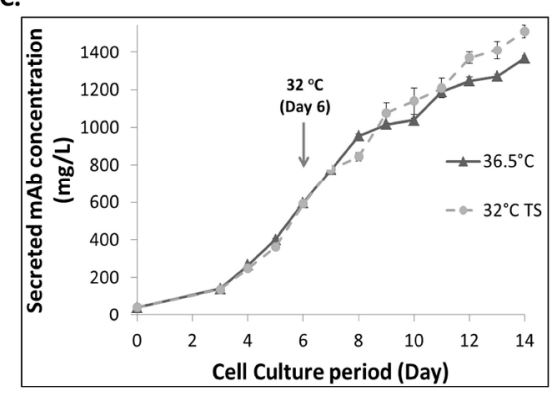

Figure 2. Cell growth and specific productivity (qmAb) of secreted IgG at $36.5^{\circ} \mathrm{C}$ and with a temperature shift to $32^{\circ} \mathrm{C}$. Viable cell concentration and cell viability profiles were measured along the period of cell culture $(A)$, together with the qmAb $(B)$ which was calculated based on terminal secreted product, and accumulated $\mathrm{mAb}$ concentration profile $(\mathrm{C})$ of both temperatures. Results were average measurements from 6 experimental data sets at $36.5^{\circ} \mathrm{C}(n=6)$ and 3 data sets at $32^{\circ} \mathrm{C}(n=3)$. The error bars represent the standard deviation of the six- and triplicate samples in two cases. TS: Temperature shift. $209 \times 148 \mathrm{~mm}(300 \times 300$ DPI) 
A.

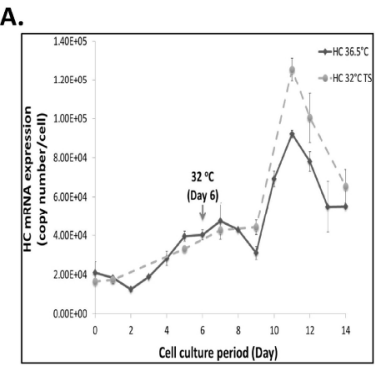

D.

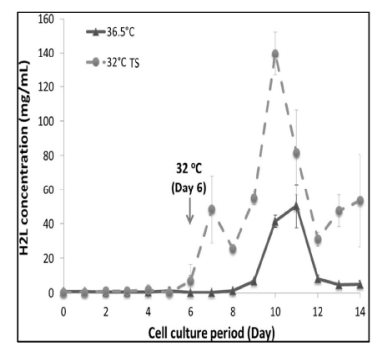

B.
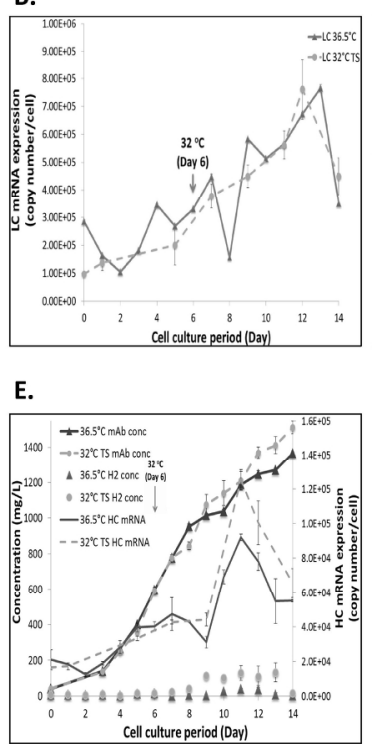

C.

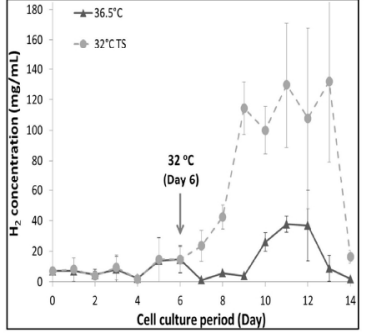

Figure 3. Concentration profiles of heavy (A) and light chain (B) mRNA and H2 (C), H2L (D) intracellular assembly intermediates of IgG molecules at $36.5^{\circ} \mathrm{C}$ and $32^{\circ} \mathrm{C}$ TS. The overlay profiles of HC mRNA copy number, accumulated $\mathrm{mAb}$ and $\mathrm{H} 2$ concentrations (E) suggested heavy chain to be rate determining species in mild hypothermic condition. Results were average measurements from 6 experimental data sets at $36.5^{\circ} \mathrm{C}(n=6)$ and 3 data sets at $32^{\circ} \mathrm{C}$ TS $(n=3)$. The error bars represent the standard deviation of the sixand triplicate samples in two cases. TS: Temperature shift. $209 \times 148 \mathrm{~mm}(300 \times 300$ DPI $)$ 
1

2

3

4

5

6

7

8

9

10

11

12

13

14

15

16

17

18

19

20

21

22

23

24

25

26

27

28

29

30

31

32

33

34

35

36

37

38

39

40

41

42

43

44

45

46

47

48

49

50

51

52

53

54

55

56

57

58

59

60
A.

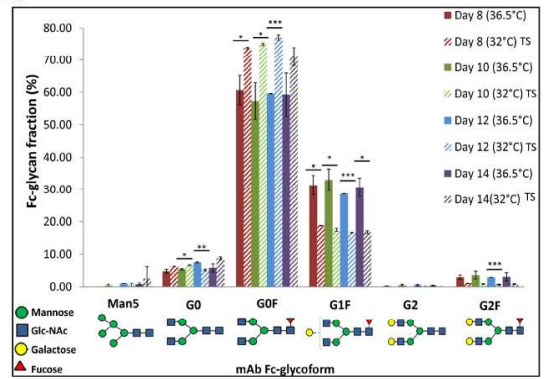

c.

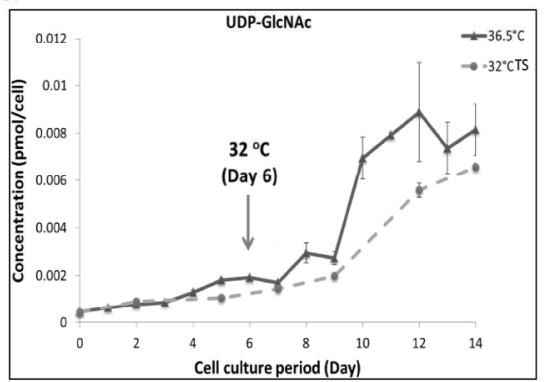

B.

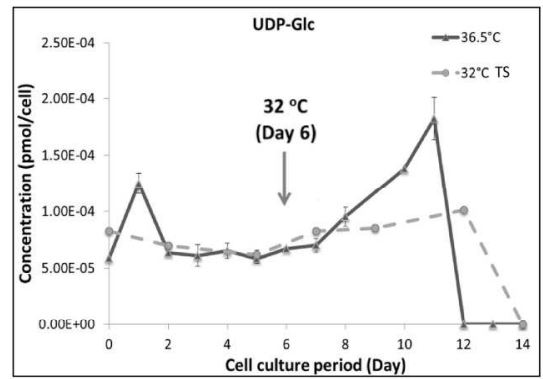

D.

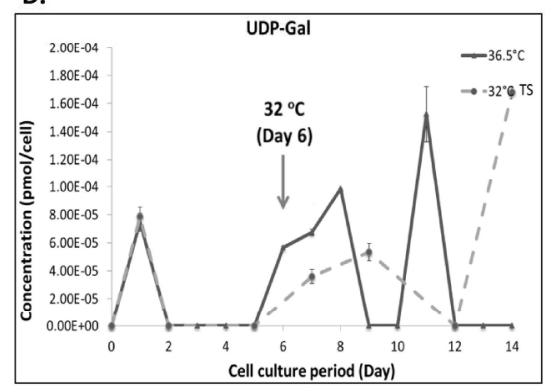

Figure 4. Glycan and NSD profile of the secreted IgG. Fractions of 6 glycan structures (A): Man5, G0, G0F, G1F, G2 and G2F on the secreted IgG products were determined, together with concentrations of UDP-Glc

(B), UDP-GIcNAc (C) and UDP-Gal (D) that were experimentally measured. Results were average measurements from 6 experimental data sets at $36.5^{\circ} \mathrm{C}(n=6)$ and 3 data sets at $32^{\circ} \mathrm{C}$ TS $(n=3)$. The error bars represent the standard deviation of the six- and triplicate samples in two cases. Statistical significance was calculated and was represented by: $\mathrm{p} \leq 0.05(*), \mathrm{p} \leq 0.01(* *)$ and $\mathrm{p} \leq 0.001(* * *)$. TS: Temperature shift. $209 \times 148 \mathrm{~mm}(300 \times 300$ DPI $)$ 


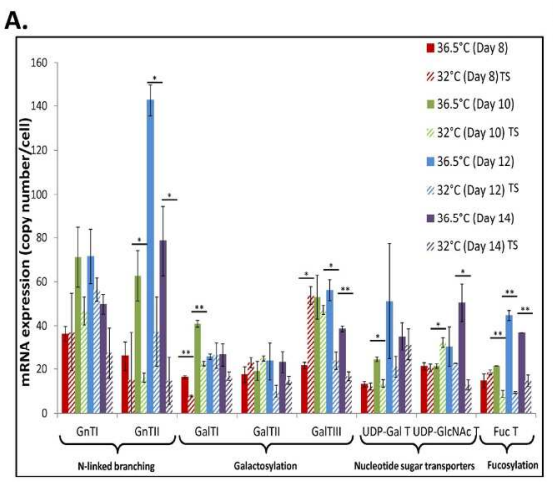

B.

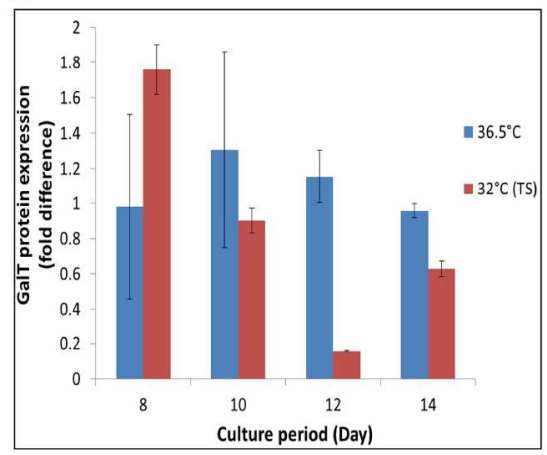

Figure 5. Expression profile of protein $\mathrm{N}$-linked glycosylation enzymes $(\mathrm{A})$ and relative difference in galactosyltransferase III (GalTIII) protein expression (B). Results were average measurements from 6 experimental data sets at $36.5^{\circ} \mathrm{C}(n=6)$ and 3 data sets at $32^{\circ} \mathrm{C}$ TS $(n=3)$. The error bars represent the standard deviation of the six- and tri-plicate samples in two cases. Statistical significance was calculated and was represented by: $\mathrm{p} \leq 0.05(*), \mathrm{p} \leq 0.01(* *)$ and $\mathrm{p} \leq 0.001(* * *)$.TS: Temperature shift. $209 \times 148 \mathrm{~mm}(300 \times 300 \mathrm{DPI})$ 
1

2

3

4

5

6

7

8

9

10

11

12

13

14

15

16

17

18

19

20

21

22

23

24

25

26

27

28

29

30

31

32

33

34

35

36

37

38

39

40

41

42

43

44

45

46

47

48

49

50

51

52

53

54

55

56

57

58

59

60

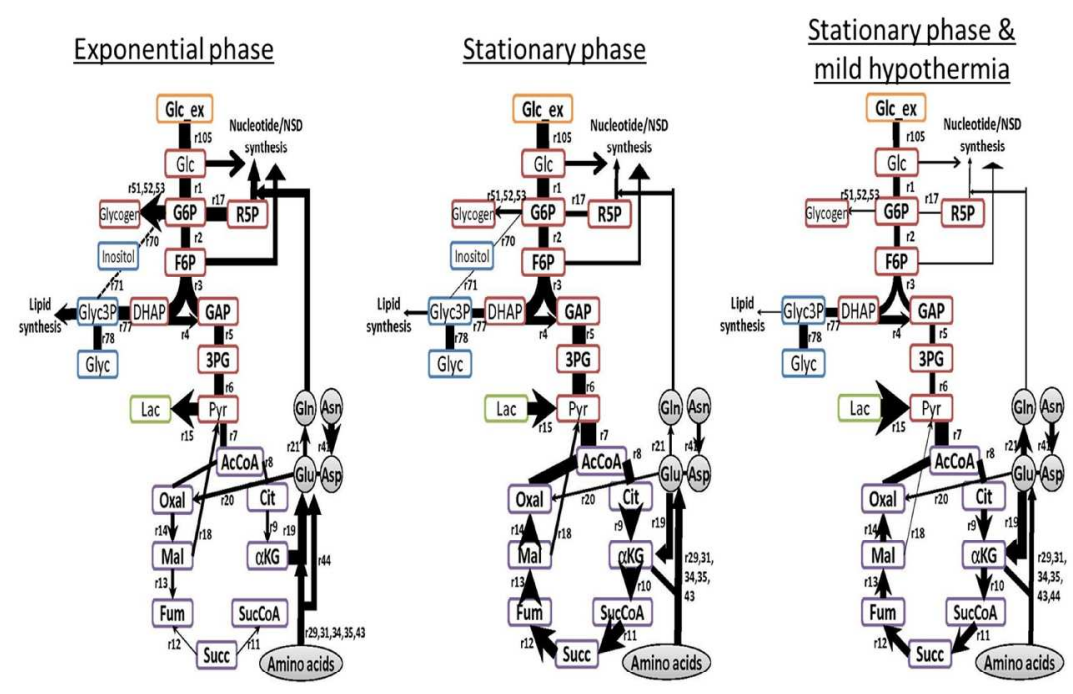

Figure 6. Central carbon metabolism of $\mathrm{CHO}$ cells at exponential growth (days 3-6), stationary phase (days $7-10)$ at $36.5^{\circ} \mathrm{C}$ and stationary phase coupled with mild hypothermia. Thickness of an arrow indicates the relative flow of the carbon source within the system. This figure is simplified to include carbon lost to glycerol, glycogen and lactate production, together nucleotide, NSD, lipid and key amino acid synthesis. $209 \times 148 \mathrm{~mm}(300 \times 300 \mathrm{DPI})$ 

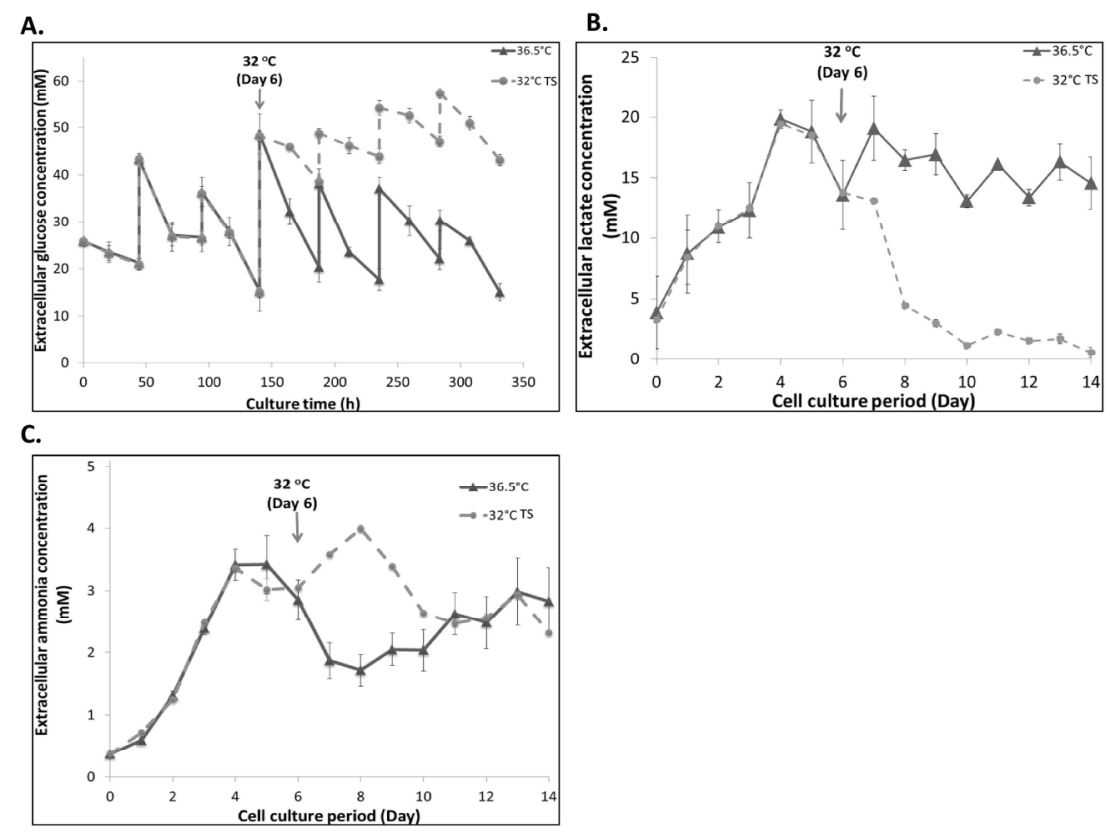

Figure 7. Overview of extracellular metabolite concentrations. Concentration profiles of extracellular glucose (A), lactate (B) and ammonia (C) when $\mathrm{CHO}$ cells were culture at $36.5^{\circ} \mathrm{C}$ or under mild hypothermia at $32^{\circ} \mathrm{C}$ introduced on day 6 . Results were average measurements from 6 experimental data sets at $36.5^{\circ} \mathrm{C}(\mathrm{n}=6)$ and 3 data sets at $32^{\circ} \mathrm{C}(n=3)$. The error bars represent the standard deviation of the six- and triplicate samples in two cases. TS: Temperature shift. $209 \times 148 \mathrm{~mm}(300 \times 300 \mathrm{DPI})$ 
Figure 8. An overview of the impact of mild hypothermia on mAb glycosylation. $209 \times 148 \mathrm{~mm}(300 \times 300$ DPI $)$ 
Table 1 . Overview of heavy and light chain mRNA stability at $36.5^{\circ} \mathrm{C}$ and with temperature-shifted to $32^{\circ} \mathrm{C}$ on day 6 .

$209 \times 148 \mathrm{~mm}(300 \times 300$ DPI $)$ 
Table 2. Average specific metabolic production and consumption rates for $36.5^{\circ} \mathrm{C}$ and with temperatureshifted to $32^{\circ} \mathrm{C}$ on day 6 . Average rates were calculated from 6 sets and 3 sets of experimental data that was carried out at $36.5^{\circ} \mathrm{C}$ and with temperature shift, respectively. All species are shown in femtolmol/cell/day except $\mu$ which has units of 1/day. Exponential phase: days 3-6; stationary phase: days7-10. Negative value indicates consumption. TS: Temperature shift. $209 \times 148 \mathrm{~mm}(300 \times 300$ DPI $)$ 
Supplementary Table 1. Forward and reverse primer pairs used in qRT-PCR experiments.

\begin{tabular}{|c|c|c|}
\hline \multicolumn{3}{|c|}{ Branching: N-acetylglucosaminyl Transferases (GnT) } \\
\hline GnT I & & $\begin{array}{l}\text { 5'-CTGGGTGTCATGGATGACCT-3' } \\
\text { 5'-CTAATTCCAGCTAGGATC-3' }\end{array}$ \\
\hline GnT II & & $\begin{array}{l}\text { 5'-GATGATTATAACTGGGACTGG-3' } \\
\text { 5'-TGACTCAATTTGGGCACTCTG-3' }\end{array}$ \\
\hline \multicolumn{3}{|c|}{ Galactosylation: Galactosyltransferases ( $\beta-G a l$ T) } \\
\hline$\beta-G a l$ T I & AF318896 & $\begin{array}{l}\text { 5'-GACCTGGAGCTTTTGGCAAA-3', } \\
\text { 5'-GGGATAATGATGGCCACCTTG-3' }\end{array}$ \\
\hline$\beta$-Gal T II & AY117536 & $\begin{array}{l}\text { 5'-CCTTCTCTGCCTGCTGCACT-3' } \\
\text { 5'-CTGGGCTTCGGATACTGAAGC-3' }\end{array}$ \\
\hline$\beta$-Gal T III & AY117537 & $\begin{array}{l}\text { 5'-AACTGCCATAATTGTGCCCC-3' } \\
\text { 5'-TGCCATATGCAAGCTGCTG-3' }\end{array}$ \\
\hline \multicolumn{3}{|l|}{ Fucosylation } \\
\hline Fucosyltransferase & & $\begin{array}{l}\text { 5'-TATGGCACCCAGCGAACACTC-3' } \\
\text { 5'-TTCACCTGACCAGTGTCCAG-3' }\end{array}$ \\
\hline \multicolumn{3}{|c|}{ Nucleotide Sugar Transporters } \\
\hline UDP-Gal Transporter & AF299335 & $\begin{array}{l}\text { 5'-ACACACTCAAGCTCGCGGT-3' } \\
\text { 5'-TGTCACCTGGAAAGTGGCAG-3' }\end{array}$ \\
\hline UDP-GlcNAc Transporter & & $\begin{array}{l}\text { 5'-CAGGAGTTGCTTTTGTACAG-3' } \\
\text { 5'-GCTGTGAGAACTGCCATGAG-3' }\end{array}$ \\
\hline
\end{tabular}

*Primer sequence for the heavy and light chain can be provided upon request. 
Supplementary Table 2. FBA reactions of $\mathrm{CHO}$ cells included in the model.

\begin{tabular}{|c|c|c|}
\hline \# & Reaction & Reversibility \\
\hline & Glycolysis & \\
\hline 1 & {$[c]:$ Glc + ATP -.> G6P + ADP } & Irreversible \\
\hline 2 & {$[c]: G 6 P<==>$ F6P } & Reversible \\
\hline 3 & {$[c]:$ F6P + ATP --> DHAP + GAP + ADP } & Irreversible \\
\hline 4 & {$[c]:$ DHAP $<==>$ GAP } & Reversible \\
\hline 5 & {$[c]:$ GAP + NAD + ADP $<==>3 P G+N A D H+A T P$} & Reversible \\
\hline \multirow[t]{2}{*}{6} & {$[c]: 3 P G+A D P$--> Pyr + ATP } & Irreversible \\
\hline & TCA cycle & \\
\hline 7 & {$[c]:$ Pyr + NAD + CoASH --> AcCoA + CO2 + NADH } & Irreversible \\
\hline 8 & {$[c]:$ AcCoA + Oxal --> Cit + CoASH } & Irreversible \\
\hline 9 & {$[c]:$ Cit + NADP --> $\alpha K G+C O 2+N A D P H$} & Irreversible \\
\hline 10 & {$[c]: \alpha K G+$ CoASH + NAD --> SucCoA + CO2 + NADH } & Irreversible \\
\hline 11 & {$[c]$ : SucCoA + GDP $<==>$ Succ + GTP + CoASH } & Reversible \\
\hline 12 & {$[c]$ : Succ + FAD $<==>$ Fum + FADH2 } & Reversible \\
\hline 13 & {$[c]:$ Fum $<==>$ Mal } & Reversible \\
\hline \multirow[t]{2}{*}{14} & {$[c]: \mathrm{Mal}+\mathrm{NAD}<==>\mathrm{Oxal}+\mathrm{NADH}$} & Reversible \\
\hline & Pyruvate fates & \\
\hline 15 & {$[c]:$ Pyr + NADH <==> Lac + NAD } & Reversible \\
\hline \multirow{2}{*}{16} & {$[\mathrm{c}]:$ Pyr + Glu <==> Ala $+\alpha$ KG } & Reversible \\
\hline & Pentose Phosphate Pathway & \\
\hline \multirow[t]{2}{*}{17} & [c] : (3) G6P + (6) NADP --> (3) CO2 + (3) R5P + (6) NADPH & Irreversible \\
\hline & Anaplerotic Reaction & \\
\hline \multirow[t]{2}{*}{18} & {$[\mathrm{c}]: \mathrm{Mal}+\mathrm{NADP}<==>$ Pyr + HCO3 + NADPH } & Reversible \\
\hline & Amino Acid Metabolism & \\
\hline 19 & {$[c]:$ Glu + NADP $<==>\alpha K G+N H 4+N A D P H$} & Reversible \\
\hline 20 & {$[c]:$ Oxal + Glu $<==>$ Asp $+\alpha K G$} & Reversible \\
\hline 21 & {$[c]: G \ln +A D P<==>$ Glu $+A T P+N H 4$} & Reversible \\
\hline 22 & {$[c]:$ Thr + NAD + CoASH --> Gly + NADH + AcCoA } & Irreversible \\
\hline 23 & {$[c]:$ Ser + THF + NADP <==> Gly + NADPH + N10FTHF } & Reversible \\
\hline 24 & {$[c]:$ N10FTHF + ADP <==> ATP + Formate + THF } & Reversible \\
\hline 25 & {$[c]:$ Ser --> Pyr + NH4 } & Irreversible \\
\hline 26 & {$[c]:$ Thr $-->\alpha K b+N H 4$} & Irreversible \\
\hline 27 & {$[c]: \alpha \mathrm{Kb}+\mathrm{COASH}+\mathrm{NAD}+\mathrm{HCO} 3+\mathrm{ATP}$--> SUCCOA + ADP + NADH + CO2 } & Irreversible \\
\hline 28 & [c] : Trp --> Ala + (2) CO2 + aKa & Irreversible \\
\hline 29 & {$[c]:$ Lys + (2) $\alpha \mathrm{KG}+$ (3) NADP + FAD --> $\alpha \mathrm{Ka}+$ (2) Glu + (3) NADPH + FADH2 } & Irreversible \\
\hline 30 & {$[c]: \alpha \mathrm{Ka}+(2) \mathrm{CoASH}+(2) \mathrm{NAD}-->$ (2) AcCoA + (2) NADH + (2) CO2 } & Irreversible \\
\hline 31 & {$[\mathrm{c}]: \mathrm{Val}+\alpha \mathrm{KG}+\mathrm{CoASH}+\mathrm{NAD}$--> IsobutCoA + Glu + CO2 + NADH } & Irreversible \\
\hline 32 & {$[c]$ : IsobutCoA + FAD + (2) NAD + HCO3 + ATP --> SucCoA + ADP + FADH2 + (2) NADH + CO2 } & Irreversible \\
\hline 33 & [c] : IsobutCoA --> Isobut & Irreversible \\
\hline 34 & $\begin{array}{l}{[\mathrm{c}]: \text { : Ile + } \alpha \mathrm{KG}+(2) \mathrm{COASH}+(2) \mathrm{NAD}+\mathrm{FAD}+\mathrm{HCO3}+\mathrm{ATP} \text {--> AcCoA + SucCoA + ADP + Glu + CO2 + (2) }} \\
\mathrm{NADH}+\mathrm{FADH} 2\end{array}$ & Irreversible \\
\hline 35 & {$[\mathrm{c}]$ : Leu + $\alpha$ KG + CoASH + NAD --> IsovalCoA + Glu + CO2 + NADH } & Irreversible \\
\hline 36 & {$[c]$ : IsovalCoA + FAD + ATP + CO2 + SucCoA + CoASH --> (3) AcCoA + Succ + FADH2 + ADP } & Irreversible \\
\hline 37 & [c] : IsovalCoA --> Isoval & Irreversible \\
\hline 38 & {$[c]:$ Phe + NADH --> Tyr + NAD } & Irreversible \\
\hline 39 & [c] : Tyr + aKG + SucCoA + CoASH --> Fum + (2) AcCoA + Succ + Glu + CO2 & Irreversible \\
\hline 40 & {$[c]:$ Met + Ser + ATP $-->\alpha K b+N H 4+$ AMP } & Irreversible \\
\hline 41 & {$[c]:$ Asn $<==>$ Asp $+\mathrm{NH} 4$} & Reversible \\
\hline 42 & {$[c]:$ Pro + NADP $<==>$ Glu + NADPH } & Reversible \\
\hline 43 & {$[c]:$ Arg + $\alpha$ KG + NADP --> (2) Glu + NADPH + Urea } & Irreversible \\
\hline 44 & {$[c]:$ His $-->$ Glu $+\mathrm{NH} 4$} & Irreversible \\
\hline 45 & {$[c]:$ Arg $->$ Orn + Urea } & Irreversible \\
\hline 46 & {$[\mathrm{c}]:$ Orn --> PTRSC + CO2 } & Irreversible \\
\hline 47 & {$[c]:$ Met + ATP --> SAM } & Irreversible \\
\hline 48 & {$[c]:$ SAM --> DSAM + CO2 } & Irreversible \\
\hline
\end{tabular}




\begin{tabular}{|c|c|c|}
\hline 49 & [c] : DSAM + PTRSC --> 5MTA + SPRMD & Irreversible \\
\hline \multirow[t]{2}{*}{50} & [c] : 5MTA + SPRM --> DSAM + SPRMD & Irreversible \\
\hline & Glycogen Synthesis & \\
\hline 51 & [c] : G6P --> G1P & Irreversible \\
\hline 52 & [c] : G1P + UMPRN + (2) ATP --> UDPG + (2) ADP & Irreversible \\
\hline \multirow[t]{2}{*}{53} & [c] : UDPG --> Glycogen + UDP & Irreversible \\
\hline & Nucleotide Synthesis & \\
\hline 54 & [c] : R5P + ATP --> PRPP + AMP & Irreversible \\
\hline 55 & [c] : PRPP + (2) Gln + Gly + Asp + (5) ATP + CO2 + (2) N10FTHF --> IMP + (2) Glu + Fum + (5) ADP + (2) THF & Irreversible \\
\hline 56 & [c] : IMP + Asp + GTP --> AMPRN + Fum + GDP & Irreversible \\
\hline 57 & [c] : IMP + Gln + ATP + NAD --> GMPRN + Glu + AMP + NADH & Irreversible \\
\hline 58 & [c] : HCO3 + NH4 + Asp + (2) ATP + NAD --> Orotate + (2) ADP + NADH & Irreversible \\
\hline 59 & [c] : Orotate + PRPP --> UMPRN + CO2 & Irreversible \\
\hline 60 & [c] : UMPRN + Gln + ATP --> CMPRN + Glu + ADP & Irreversible \\
\hline 61 & [c] : AMPRN --> dAMP & Irreversible \\
\hline 62 & [c] : GMPRN --> dGMP & Irreversible \\
\hline 63 & [c] : CMPRN --> dCMP & Irreversible \\
\hline \multirow[t]{2}{*}{64} & [c] : UMPRN --> dTMP & Irreversible \\
\hline & Lipid Synthesis & \\
\hline 65 & [c] : Choline + ATP --> Pcholine + ADP & Irreversible \\
\hline 66 & $\begin{array}{l}\text { [c] : Pcholine + (18) AcCoA + Glyc3P + (22) ATP + (33) NADH --> PC + (16) ADP + (6) AMP + (33) NAD + (18) } \\
\text { CoASH }\end{array}$ & Irreversible \\
\hline 67 & [c] : PC + Ser <==> PS + Choline & Reversible \\
\hline 68 & {$[c]:$ PS --> PE + CO2 } & Irreversible \\
\hline 69 & [c] : Choline + Glyc3P <==> Glyc3PC & Reversible \\
\hline 70 & [c] : G6P --> Inositol & Irreversible \\
\hline 71 & $\begin{array}{l}\text { [c] : Inositol + (18) AcCoA + Glyc3P + (22) ATP + (33) NADH --> PI + (16) ADP + (6) AMP + (33) NAD + (18) } \\
\text { CoASH }\end{array}$ & Irreversible \\
\hline 72 & [c] : (18) AcCoA + (2) Glyc3P + (22) ATP + (33) NADH --> PG + (16) ADP + (6) AMP + (33) NAD + (18) CoASH & Irreversible \\
\hline 73 & [c] : (2) PG --> DPG + Glyc & Irreversible \\
\hline 74 & $\begin{array}{l}\text { [c] : (16) AcCoA + Ser + Choline + (16) ATP + (29) NADPH --> SM + (2) CO2 + (14) ADP + (2) AMP + (29) } \\
\text { NADP + (16) CoASH }\end{array}$ & Irreversible \\
\hline \multirow[t]{2}{*}{75} & [c] : (18) AcCoA + (18) ATP + (14) NADPH --> Cholesterol + (9) CO2 + (18) ADP + (14) NADP + (18) CoASH & Irreversible \\
\hline & Biomass Formation & \\
\hline \multirow[t]{2}{*}{76} & 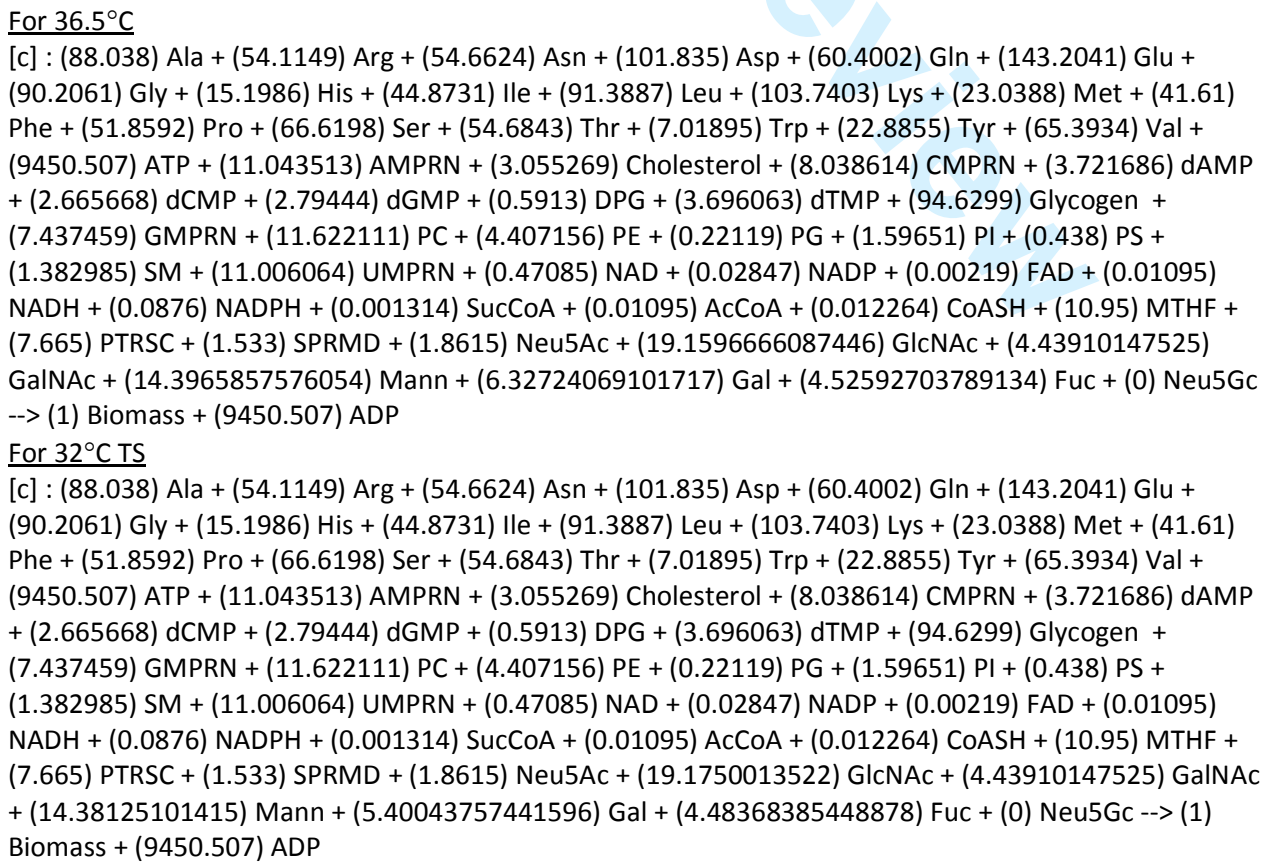 & Irreversible \\
\hline & Other by-products & \\
\hline 77 & [c] : AcCoA + AMP <==> Acetate + CoASH + ATP & Reversible \\
\hline
\end{tabular}


2

3

4

\begin{tabular}{|c|c|c|}
\hline 78 & [c] : DHAP + NADH <==> Glyc3P + NAD & Reversible \\
\hline \multirow[t]{2}{*}{79} & [c] : Glyc3P <==> Glyc & Reversible \\
\hline & Glycosylation & \\
\hline 80 & [c] : UDPG <==> UDPGal & Reversible \\
\hline 81 & [c] : Glc + ATP + GTP --> GDPMann + ADP & Irreversible \\
\hline 82 & [c] : F6P + GIn + AcCoA + UTP --> UDPNAG + Glu + CoASH & Irreversible \\
\hline 83 & [c] : UDPNAG + ATP + 3PG + CTP --> CMPNeu5Ac + UDP + ADP & Irreversible \\
\hline 84 & [c] : GDPMann + NADPH --> GDPFuc + NADP & Irreversible \\
\hline 85 & [c] : UDPNAG <==> UDP + GIcNAc & Reversible \\
\hline 86 & [c] : UDPNAG <==> UDPGaINAc & Reversible \\
\hline 87 & [c] : UDPGalNAc <==> GalNAc + UDP & Reversible \\
\hline 88 & [c] : GDPMann <==> Mann + GDP & Reversible \\
\hline 89 & [c] : UDPGal <==> Gal + UDP & Reversible \\
\hline 90 & [c] : CMPNeu5Ac <==> CMP + Neu5Ac & Reversible \\
\hline 91 & [c] : GDPFuc <==> GDP + Fuc & Reversible \\
\hline 92 & [c] : CMPNeu5Ac <==> CMPNeu5Gc & Reversible \\
\hline \multirow[t]{2}{*}{93} & [c] : CMPNeu5Gc <==> CMP + Neu5Gc & Reversible \\
\hline & Vitamin metabolism & \\
\hline 94 & [c] : Fol + NADH --> THF + NAD & Reversible \\
\hline 95 & {$[\mathrm{c}]: \mathrm{Gly}+\mathrm{THF}+\mathrm{NAD}<==>\mathrm{METTHF}+\mathrm{NH} 4+\mathrm{CO} 2+\mathrm{NADH}$} & Reversible \\
\hline \multirow[t]{2}{*}{96} & [c] : MTHF + NADP <==> METTHF + NADPH & Reversible \\
\hline & IgG Formation & \\
\hline \multirow[t]{2}{*}{97} & $\begin{array}{l}\text { [c] : (423.795512610944) Ala + (266.385750784022) Arg + (314.819523653844) Asn + } \\
(302.711080436388) \text { Asp }+(363.253296523666) \mathrm{Gln}+(363.253296523666) \mathrm{Glu}+(581.205274437866) \\
\text { Gly }+(133.192875392011) \mathrm{His}+(0) \mathrm{lle}+(605.422160872777) \mathrm{Leu}+(520.663058350588) \mathrm{Lys}+ \\
(72.6506593047332) \mathrm{Met}+(266.385750784022) \mathrm{Phe}+(532.771501568043) \text { Pro }+(1138.19366244082) \\
\text { Ser }+(593.313717655321) \mathrm{Thr}+(121.084432174555) \mathrm{Trp}+(387.470182958577) \mathrm{Tyr}+ \\
(690.181263394965) \mathrm{Val}+(10.992) \text { GDPFuc }+(54.962) \text { UDPNAG }+(32.977) \text { GDPMann }+(21.985) \text { UDPGal } \\
+(21.985) \text { CMPNeu5Ac --> (32.977) GDP }+(21.985) \text { UDP }+(21.985) \mathrm{CMP}+(1) \operatorname{lgG}\end{array}$ & Irreversible \\
\hline & Transport Reactions & \\
\hline 98 & Acetate[e] <==> & Reversible \\
\hline 99 & ADP $[\mathrm{e}]<==>$ & Reversible \\
\hline 100 & $\mathrm{Ala}[\mathrm{e}]<==>$ & Reversible \\
\hline 101 & AMP $[\mathrm{e}]<==>$ & Reversible \\
\hline 102 & $\operatorname{Arg}[\mathrm{e}]<==>$ & Reversible \\
\hline 103 & Asn[e] <==> & Reversible \\
\hline 104 & Asp $[\mathrm{e}]<==>$ & Reversible \\
\hline 105 & ATP $[$ e $]<==>$ & Reversible \\
\hline 106 & Biomass $[\mathrm{e}]<==>$ & Reversible \\
\hline 107 & Choline $[\mathrm{e}]<==>$ & Reversible \\
\hline 108 & Cit $[e]<==>$ & Reversible \\
\hline 109 & CMP $[\mathrm{e}]<==>$ & Reversible \\
\hline 110 & $\mathrm{CO} 2[\mathrm{e}]<==>$ & Reversible \\
\hline 111 & CoASH[e] <==> & Reversible \\
\hline 112 & CTP $[\mathrm{e}]<==>$ & Reversible \\
\hline 113 & $\mathrm{FAD}[\mathrm{e}]<==>$ & Reversible \\
\hline 114 & $\mathrm{FADH} 2[\mathrm{e}]<==>$ & Reversible \\
\hline 115 & Fol $[\mathrm{e}]<==>$ & Reversible \\
\hline 116 & Formate $[\mathrm{e}]<==>$ & Reversible \\
\hline 117 & Fum $[\mathrm{e}]<==>$ & Reversible \\
\hline 118 & GDP $[\mathrm{e}]<==>$ & Reversible \\
\hline 119 & GIc $[\mathrm{e}]<==>$ & Reversible \\
\hline 120 & $\mathrm{G} \ln [\mathrm{e}]<==>$ & Reversible \\
\hline 121 & Glu[e] <==> & Reversible \\
\hline 122 & Gly[e] <==>> & Reversible \\
\hline 123 & Glyc $[\mathrm{e}]<==>$ & Reversible \\
\hline 124 & Glyc3PC $[\mathrm{e}]<==>$ & Reversible \\
\hline 125 & GTP $[e]<==>$ & Reversible \\
\hline
\end{tabular}




\begin{tabular}{|c|c|c|}
\hline 126 & $\mathrm{His}[\mathrm{e}]<==>$ & Reversible \\
\hline 127 & $\lg G[\mathrm{e}]<==>$ & Reversible \\
\hline 128 & $\| \mathrm{e}[\mathrm{e}]<==>$ & Reversible \\
\hline 129 & Isobut $[\mathrm{e}]<==>$ & Reversible \\
\hline 130 & Isoval[e] <==> & Reversible \\
\hline 131 & $\operatorname{Lac}[\mathrm{e}]<==>$ & Reversible \\
\hline 132 & Leu[e] <==> & Reversible \\
\hline 133 & Lys $[e]<==>$ & Reversible \\
\hline 134 & Mal $[\mathrm{e}]<==>$ & Reversible \\
\hline 135 & Met $[\mathrm{e}]<==>$ & Reversible \\
\hline 136 & NAD $[\mathrm{e}]<==>$ & Reversible \\
\hline 137 & $\mathrm{NADH}[\mathrm{e}]<==>$ & Reversible \\
\hline 138 & NADP $[e]<==>$ & Reversible \\
\hline 139 & NADPH[e] $<==>$ & Reversible \\
\hline 140 & $\mathrm{NH} 4[\mathrm{e}]<==>$ & Reversible \\
\hline 141 & Pcholine $[\mathrm{e}]<==>$ & Reversible \\
\hline 142 & Phe[e] <==> & Reversible \\
\hline 143 & Pro[e] <==> & Reversible \\
\hline 144 & $\operatorname{Pyr}[\mathrm{e}]<==>$ & Reversible \\
\hline 145 & $\operatorname{Ser}[\mathrm{e}]<==>$ & Reversible \\
\hline 146 & SPRM $[\mathrm{e}]<==>$ & Reversible \\
\hline 147 & Succ $[\mathrm{e}]<==>$ & Reversible \\
\hline 148 & $\operatorname{Thr}[\mathrm{e}]<==>$ & Reversible \\
\hline 149 & $\operatorname{Trp}[\mathrm{e}]<==>$ & Reversible \\
\hline 150 & $\operatorname{Tyr}[\mathrm{e}]<==>$ & Reversible \\
\hline 151 & UDP $[\mathrm{e}]<==>$ & Reversible \\
\hline 152 & Urea[e] <==> & Reversible \\
\hline 153 & UTP $[$ e $]<==>$ & Reversible \\
\hline 154 & $\operatorname{Val}[\mathrm{e}]<==>$ & Reversible \\
\hline
\end{tabular}


Supplementary Table 3. FBA estimated flux values in nucleotide synthesis, lipid synthesis and protein glycosylation during stationary phase at $36.5^{\circ} \mathrm{C}$ and $32^{\circ} \mathrm{C}$.

\begin{tabular}{|c|c|c|c|c|c|}
\hline \multirow[t]{2}{*}{ Reaction } & \multirow{2}{*}{\multicolumn{2}{|c|}{ Equation }} & \multirow[t]{2}{*}{ Subsystem } & \multicolumn{2}{|c|}{$\begin{array}{c}\text { Flux value } \\
\text { (femtomol/cell/day) }\end{array}$} \\
\hline & & & & $\begin{array}{c}36.5^{\circ} \mathrm{C} \\
\text { (Day7-10) }\end{array}$ & $\begin{array}{c}32^{\circ} \mathrm{C} \\
\text { (Day7-10) }\end{array}$ \\
\hline 54 & [c] : R5P + ATP --> PRPP + AMP & Irreversible & Nucleotide & 6.26 & 0.30 \\
\hline 55 & $\begin{array}{l}{[\mathrm{c}]: \mathrm{PRPP}+(2) \mathrm{Gln}+\mathrm{Gly}+\mathrm{Asp}+(5) \mathrm{ATP}+\mathrm{CO} 2+(2)} \\
\mathrm{N} 10 \mathrm{FTHF}-->\mathrm{IMP}+(2) \mathrm{Glu}+\mathrm{Fum}+(5) \mathrm{ADP}+(2) \mathrm{THF}\end{array}$ & Irreversible & Nucleotide & 1.00 & 0.00 \\
\hline 56 & {$[\mathrm{c}]:$ IMP + Asp + GTP --> AMPRN + Fum + GDP } & Irreversible & Nucleotide & 0.59 & 0.00 \\
\hline 57 & $\begin{array}{l}{[c]: \text { IMP + Gln + ATP + NAD --> GMPRN + Glu + }} \\
\text { AMP + NADH }\end{array}$ & Irreversible & Nucleotide & 0.41 & 0.00 \\
\hline 58 & $\begin{array}{l}{[\mathrm{c}]: \mathrm{HCO} 3+\mathrm{NH} 4+\mathrm{Asp}+(2) \mathrm{ATP}+\mathrm{NAD}-->} \\
\text { Orotate + (2) ADP + NADH }\end{array}$ & Irreversible & Nucleotide & 5.26 & 0.30 \\
\hline 59 & {$[\mathrm{c}]:$ Orotate + PRPP --> UMPRN + CO2 } & Irreversible & Nucleotide & 5.26 & 0.30 \\
\hline 60 & [c] : UMPRN + Gln + ATP --> CMPRN + Glu + ADP & Irreversible & Nucleotide & 0.43 & 0.00 \\
\hline 61 & {$[\mathrm{c}]:$ AMPRN --> dAMP } & Irreversible & Nucleotide & 0.15 & 0.00 \\
\hline 62 & [c] : GMPRN --> dGMP & Irreversible & Nucleotide & 0.11 & 0.00 \\
\hline 63 & [c] : CMPRN --> dCMP & Irreversible & Nucleotide & 0.11 & 0.00 \\
\hline 64 & [c] : UMPRN --> dTMP & Irreversible & Nucleotide & 0.15 & 0.00 \\
\hline 65 & [c] : Choline + ATP --> Pcholine + ADP & Irreversible & Lipid & 2.77 & 2.63 \\
\hline 66 & $\begin{array}{l}\text { [c] : Pcholine + (18) AcCoA + Glyc3P + (22) ATP + } \\
\text { (33) NADH --> PC + (16) ADP + (6) AMP + (33) NAD } \\
+ \text { (18) CoASH }\end{array}$ & Irreversible & Lipid & 0.66 & 0.00 \\
\hline 67 & [c] : PC + Ser $<==>$ PS + Choline & Reversible & Lipid & 0.19 & 0.00 \\
\hline 68 & {$[c]:$ PS --> PE + CO2 } & Irreversible & Lipid & 0.18 & 0.00 \\
\hline 69 & {$[\mathrm{c}]:$ Choline + Glyc $3 \mathrm{P}<==>$ Glyc3PC } & Reversible & Lipid & 3.53 & 3.53 \\
\hline 70 & [c] : G6P --> Inositol & Irreversible & Lipid & 0.06 & 0.00 \\
\hline 71 & $\begin{array}{l}\text { [c] : Inositol + (18) AcCoA + Glyc3P + (22) ATP + (33) } \\
\text { NADH --> PI + (16) ADP + (6) AMP + (33) NAD + } \\
\text { (18) CoASH }\end{array}$ & Irreversible & Lipid & 0.06 & 0.00 \\
\hline 72 & $\begin{array}{l}{[\mathrm{c}]:(18) \mathrm{AcCoA}+(\text { (2) Glyc3P + (22) ATP + (33) NADH }--} \\
>\mathrm{PG}+(16) \mathrm{ADP}+\text { (6) AMP + (33) NAD + (18) CoASH }\end{array}$ & Irreversible & Lipid & 0.06 & 0.00 \\
\hline 73 & [c] : (2) PG --> DPG + Glyc & Irreversible & Lipid & 0.02 & 0.00 \\
\hline 74 & $\begin{array}{l}\text { [c] : (16) AcCoA + Ser + Choline + (16) ATP + (29) } \\
\text { NADPH --> SM + (2) CO2 + (14) ADP + (2) AMP + } \\
\text { (29) NADP + (16) CoASH }\end{array}$ & Irreversible & Lipid & 0.06 & 0.00 \\
\hline 75 & $\begin{array}{l}{[c]:(18) \text { AcCoA + (18) ATP + (14) NADPH --> }} \\
\text { Cholesterol + (9) CO2 + (18) ADP + (14) NADP + (18) } \\
\text { CoASH }\end{array}$ & Irreversible & Lipid & 0.12 & 0.00 \\
\hline 79 & {$[\mathrm{c}]: \mathrm{UDPG}<==>$ UDPGal } & Reversible & Glycosylation & 0.46 & 0.30 \\
\hline 80 & {$[c]:$ Glc + ATP + GTP --> GDPMann + ADP } & Irreversible & Glycosylation & 1.17 & 0.61 \\
\hline 81 & {$[\mathrm{c}]: \mathrm{F} 6 \mathrm{P}+\mathrm{Gln}+\mathrm{AcCoA}+\mathrm{UTP}$--> UDPNAG + Glu + CoASH } & Irreversible & Glycosylation & 1.53 & 0.76 \\
\hline 82 & $\begin{array}{l}\text { [c] : UDPNAG + ATP + 3PG + CTP --> } \\
\text { CMPNeu5Ac + UDP + ADP }\end{array}$ & Irreversible & Glycosylation & 0.07 & 0.00 \\
\hline 83 & [c] : GDPMann + NADPH --> GDPFuc + NADP & Irreversible & Glycosylation & 0.28 & 0.15 \\
\hline 84 & [c] : UDPNAG $<=\Rightarrow$ UDP + GlcNAc & Reversible & Glycosylation & 0.78 & 0.00 \\
\hline 85 & [c] : UDPNAG $<==>$ UDPGalNAc & Reversible & Glycosylation & 0.18 & 0.00 \\
\hline 86 & [c] : UDPGalNAc $<==>$ GalNAc + UDP & Reversible & Glycosylation & 0.18 & 0.00 \\
\hline 87 & [c] : GDPMann $<==>$ Mann + GDP & Reversible & Glycosylation & 0.58 & 0.00 \\
\hline 88 & {$[\mathrm{c}]: \mathrm{UDPGal}<==>\mathrm{Gal}+\mathrm{UDP}$} & Reversible & Glycosylation & 0.25 & 0.00 \\
\hline 89 & {$[\mathrm{c}]:$ CMPNeu5Ac $<==>$ CMP + Neu5Ac } & Reversible & Glycosylation & 0.07 & 0.00 \\
\hline 90 & {$[\mathrm{c}]:$ GDPFuc $<==>$ GDP + Fuc } & Reversible & Glycosylation & 0.18 & 0.00 \\
\hline
\end{tabular}




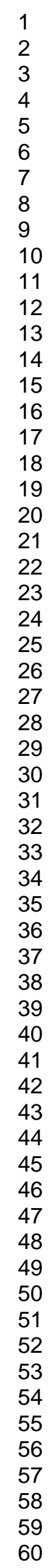

